\title{
Effect of Electrical Stimulation of the Limbic System on Pituitary-Thyroidal Function
}

\section{Fukashi MATSUZAKI}

Third Department of Internal Medicine, University of Tokyo, Faculty of Medicine

(Director : Professor Shigeo Okinaka)

The regulation of pituitary-thyroidal function through the central nervous system has been the subject of many studies, most of them dealing with the hypothalamus. The limbic system has been known to play an important role in autonomic nervous regulation, and recent studies at several laboratories have revealed that this part of the brain has an intimate relation to corticotropic and gonadotropic secretion.

The effect of electrical stimulation of the posterior orbital surface on pituitary-adrenocortical function has been reported from our laboratory.

With respect to the secretion of TSH, however, a definite relationship has not been established. Yamada and Greer reported that bilateral destruction of amygdaloid nuclear complex had little effect on PTU induced goitrogenic action. In this paper the effect of electrical stimulation of the limbic system on the pituitary-thyroidal function in dogs is reported.

Stimulation of the amygdaloid nuclear complex, the posterior orbital surface and the hippocamp formation was induced in morphine anesthetized dogs which had been previously labelled with $\mathbf{I}^{131}$.

In each of four cases in which the posterior orbital surface and the amygdaloid nuclear complex were stimulated, there was no significant increase in the concentration of $\mathrm{PBI}^{131}$ and inorganic $\mathrm{I}^{131}$ in the thyroid venous blood.

In 10 cases in which the hippocampal formation was stimulated, a definite increase in both of organic and inorganic $\mathrm{I}^{131}$ in the thyroid venous blood was observed with no significant change in the thyroid venous blood flow. Significant increase in the TSH content of the jugular vein blood, assayed in 4 animals by McKenzie's method, occurred in all cases within 30 minutes. Hypophysectomy prevented the response of the thyroid to hippocampal stimulation.

\section{The Metabolic Effects of Thyroxine Analogues: Especially the Effects on the Fatty Metabolism}

By

\section{Yasuyuki SATO}

The Ist Department of Internal Medicine, Niigata University School of Medicine (Director : Professor Dr. Mitsuo Nishikawa)

Part 1. The metabolic effects of thyroxine analogues in the hypothyroid subjects;

A dissociation of various effects of analogues.

L-thyroxine, L-triiodothyronine, D-triiodothyronine and four compounds of triiodothyroformic acid group were administrated in increasing doses to hypothyroid patients, and one gouty patient was administrated D-triiodothyronine or triiodothyropropionic acid.

Vol. 38 No. 9 
1. The administration of L-thyroxine and L-triiodothyronine to myxedematous patients did not result in a marked dissociation in the decrease in serum cholesterol level and the increase basal metabolic rate.

2. In elevating the basal metabolic rate, D-triiodothyronine is approximately from 17 to 33 percent as active as L-thyroxine, acetyl triiodothyroformic acid is only from 0.1 to 0.4 percent as active as L-thyroxine, and each effect of triiodothyroformic acid, amide of triiodothyroformic acid and its methyl ester are less than from 0.1 to 0.2 percent, from 0.5 to 1.0 percent and from 0.1 to 0.2 percent of L-thyroxine.

3. It seemed that D-triiodothyronine and triiodothyroformic acid group were more effective in reducing the serum cholesterol than in increasing the basal metabolic rate. It is interesting to note that this dissociation was marked in triiodothyroformic acid group.

4. The administration of acetyl triiodothyroformic acid on hypothyroid subjects resulted in a decrease of serum uric acid and in an increase of urinary excretion of uric acid, and produced a negative phosphorus balance. In one gouty patient, a decrease of serum uric acid and an increase of urinary excretion of uric acid were observed over three months by the administration of D-triiodothyronine or triiodothyropropionic acid.

5. The rate of disappearance of triiodothyroformic acid group from the blood of hypothyroid patients was observed as half time of protein bound iodine after the cessation of chronic administration. The half time of protein bound iodine were 2.9 days for triiodothyroformic acid, 2.0 and 2.4 days for acetyl triiodothyroformic acid, 8.8 days for its amide and 4.5 days for methyl ester.

Part 2. The hypocholesterolemic effect of D-thyroxine and acetyl triiodothyroformic acid on euthyroid hypercholesterolemic patients.

D-thyroxine or acetyl triiodothyroformic acid were administrated to the ten euthyroid hypercholesterolemic patients respectively.

1. The administration of $4 \mathrm{mg}$. daily of D-thyroxine to ten euthyroid subjects produced a little elevation of basal metabolic rate. It seemed that the administration of less than 4 mg. daily of Dthyroxine failed to sustain the decreased serum cholesterol level in one or two weeks.

2. In administering $4 \mathrm{mg}$. daily of D-thyroxine, the elevation of protein bound iodine level was slight but thyroidal radioiodine uptake was markedly inhibited.

3. The administration ranging from 25 to $60 \mathrm{mg}$. daily of acetyl triiodothyroformic acid in ten euthyroid hypercholesterolemic patients produced rapid reduction of serum lipids without significant elevation of basal metabolic rate. In spite of the increase of doses, it seemed to return gradually to its pre-treatment value.

4. The administration of relatively large doses, as much as $60 \mathrm{mg}$. daily of acetyl triiodothyroformic acid from the beginning was able to produce the reduction in serum cholesterol level without significant elevation of basal metabolic rate continuously for more than three months. At present, therefore, it seems that acetyl triiodothyroformic acid is the most potent hypocholesterolemic agents among thyroxine analogues.

5. A high protein bound iodine and marked inhibition of thyroidal radioiodine uptake were observed by the administration of acetyl triiodothyroformic acid. 


\title{
Thyroxine analogues の代謝效果
}

\section{特に脂質代謝に対する効果}

\author{
新潟大学西川内科教空（指緮 西川光夫教授） \\ 佐藤康行
}

(炤和137年 6 月 4 日受付)

目

はじめに

第 1 編 Thyroxine analogues の甲状腺機 能低下症に於ける代謝効果 特に諸作用の解離についての考察

I. 緒 言

II. 対照並びに測定方法

III. 臨床結果

1. L-thyroxine $\left(\mathrm{L}-\mathrm{T}_{4}\right)$ の效果

2. 3:5:3'-L-triiodothyronine $\left(\mathrm{L}-\mathrm{T}_{\mathrm{s}}\right)$ の效果

3. 3:5:3'-D-triiodothyronine (D- $\mathrm{T}_{3}$ ) の效果

4. 3:5:3'-triiodothyroformic acid group ( $\mathbf{T}_{3}$-formic acid group) の效果

a. $\mathrm{T}_{3}$-formic acid

b. acetyl $\mathrm{T}_{3}$-formic acid

c. $\mathbf{T}_{3}$-formic acid, methyl ester

d. $\mathrm{T}_{3}$-formic acid, amide

e. $\mathrm{T}_{3}$-formic acid group の血巾消 失速度

IV. 考按並びに総括

1. L-thyroxine 及び L-triiodothyronine の作用の解離について

2. thyroxine analogues $の$ BMR 上 景作用
次

3 . thyroxine analogues $の$ BMR 上 昇作用と血清 cholesterol 低下作用と の解離

4. thyroxine analogues の燐及び尿酸 代謝に及ぼず影響

5. thyroxine analogues の低中消失速 度

$\mathrm{V}$. 結 論

第 2 編甲状腺機能正常者に於ける D-thy－ roxine 及び acetyl $\mathrm{T}_{3}$-formic acid の血清脂質低下作用

I 。緒 言

II．対照並びに测定方法

III. D-thyroxine の血清脂質低下作用

IV. acetyl $\mathrm{T}_{3}$-formic acid の血清脂質 低下作用

$\mathrm{V}$ ，考按並びに総括

1。血清脂質低下作用

1). D-thyroxine

2). acetyl $T_{3}$-formic acid

2. 心臟に対与゙る作用

3. PBI の変化

4. 甲状腺 $\mathrm{I}^{113}$ 提取渗抑制效果

VI. 結 論

\section{は じめに}

1915年，Kendall ${ }^{42}$ ) そよる $3: 5: 3^{\prime}: 5^{\prime}$-L-tetraiodothyronine 即ち L-thyroxine $\left(\mathrm{L}_{-} \mathrm{T}_{4}\right)$ の発見後，長い閒 thyroid hormone の研究は暗中模索の状態であつたが，1950年 Gross and_Pitt-Rivers ${ }^{33) 34) に よ つ て ~} 3: 5:$ 3'-L-triiodothyronine ( $\left(\mathrm{L}-\mathrm{T}_{3}\right)$ が分離されたことによつて，甲状腺 hormone の系統的研究の道が開かれた.

上記の天然に存在する hormone に対し，1952年 Hattington and Pitt-Rivers ${ }^{35)}$ にうて, 3:5:3':5'-te traiodothyroacetic acid (tetrac) が，次いで1953年 Pitt-Rivers ${ }^{61)}$ にり 3:5:3'-triiodothyroacetic acid (triac) が合成されて以来, thyroxine analogues の研究が大きく注目されるようになつた.

$$
\text { 第38巻 符 } 9 \text { 号 }
$$


一方1800年代の末期に，偶然用状腺摘出動物に動脈硬化症の発生するてとが見出され，Hurxthal ${ }^{399}$ 及び Adlersberg)等も家鬼で甲状腺を摘出すると，血清 cholesterol が著しく上昇すること热めている，又犬で は cholesterol 飼育のみでは atherosclerosis を起すととは团難といわれているが Thiouracil ${ }^{74} や I^{131} て ゙$ 甲状 腺機能を低下させると atherosclerosis 它容易に発生させうるてとが知られている.

人に於ても, 甲状腺機能低下症患者で血中 cholesterol 及び phospholipids の高值をみるととは周知の事

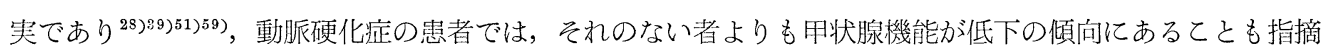
されており ${ }^{15)}$ ，更に甲状腺機能九進症では血清脂質の低下傾向か認められている ${ }^{\left.51)^{53} 360\right)}$.

以上のことからも，甲状腺が動脈硬化ならびに脂質代謝に大きな役割を有しているととが推察される.

動脈硬化症は元来, 老化の一現象として避けがたいものと考光られてきた。しかし現在, 動脈硬化症の中 少なくとも atherosclerosis は，多分その多くを脂質代識異常にもとづくものであろうとの意見が支配的で， てれを是正しようとする試みが实際的な問題となつてきつつある，ての場合，大動脈壁中の脂質は血管壁の 代謝異常にその原因を求める意見もあるが，atherosclerosis の大動脈の内膜には，正常の 260 倍にも達する cholesterol ester が含まれており ${ }^{68)}$, 局所の代謝異常のみからは説明されないといわれている。従つて現在 では, やはり atherosclerosis は全身的な脂質代謝異常に基づき, 過剩な脂質が浸透して内膜に, 又は栄養 血管を通じて中膜に蓄積されて起るという濾過説 $\left.{ }^{58}\right)^{8}$ が支配的である。にして phospholipids に対して cholesterol の相対的な上昇（C/P 比の上昇）は， cholesterol の不安定化をきたし，内膜への沈着を促進する2) という. 最近 Field ら ${ }^{23}$ は $\mathrm{C}^{14}$ を用いて, 人の動脈壁に存在する cholesterol の多くは血中より移行したも のであるととを証明している.

従つて, 近年この脂質代謝異常に対して治療的意味がもたれるようになつた。もちろん動脈硬化症の発生 は単一の原因に由来するものではなく, 種々の機転が複雑に働いているであろうことは想像にかたくない.

以上述べてき関係より，第 1 編に於て，主として thyroxine analogues の脂質代謝に及ぼす効果につい て比較検討を試み，第 2 編に於ては臨床的応用について記載する.

尚ての成績は第 8 回及び第 9 回日本内分泌学会東部々会総会, 並びに第 3 回日本老年医学会総会代於て発 表したものである.

使用した analogues は L-triiodothyronine 及び $\mathrm{T}_{3}$-formic acid group を武田薬品より, D-thyroxine を Travenol Laboratories, D-triiodothyronine te Smith-Kline \& French Laboratories 及び $\mathrm{T}_{3}$-propionic acid 老 Warner-Lambert Reserch Institute一小野薬品より供与をうけた.

第 1 編 Thyroxine analogues の甲状腺機能低下症に於ける代謝効果 特に諸作用の解離についての考察

\section{I. 緒言}

一般に thyroxine analogues はいくつかの作用を有し，それぞれの生物学的力洒の検定には次のような 方法が用いられている(3).

1.オタマジャクシの変体促進 ${ }^{\text {5 }}$ )

2. Thiouracil 投与によつて生ずる甲状腺腫を予防する作用 ${ }^{73}$

3 . 小動物の酸素消費を促進させる作用 ${ }^{73}$

4.ラットの甲状腺 $I^{13}$ 掑取率を抑制する効果 ${ }^{54)}$

5 . 移植可能なマウス下垂体腫瘍発育抑制効果 ${ }^{45}$

以上の他に臨床的な力価検定として次の如きものがある.

6 . 粘液水腫の BMR を上昇させる作用

7. 血清脂質を(低下せしめる作用 ${ }^{48}$ (50)86)

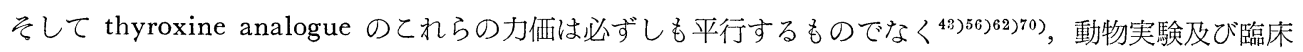




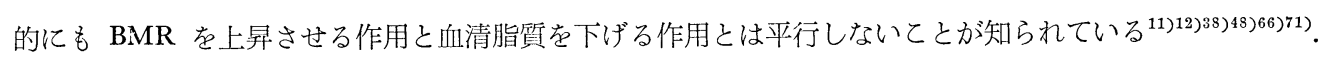

Peters $\left.^{60}\right)$ は既に1950年に，甲状機能低下症患者が乾燥甲状腺で治療された際に，他の指標よりも血清 cholesterol が速かに反応し，BMR に先立つて正常に厌るであろうと述べている，Boyd and Oliver ${ }^{11)}$ は定 条件下の実験で12種の analogues について, antigoitrogenic 酸素消費量の增加, 心搏数及び心重量の増加 並びに血清及び肝の cholesterol の低下を観察し，乙れらの方法のいずれに於ても，それぞれの analogues の dose-response curve が平行しないととを記載している.

このような thyroxine analogues の “作用の解離” が，本来の甲状腺 hormone である L-thyroxine 及 び L-triiodothyronine についてもみることができるか否かを検討した報告は少ない. 従つて本研究に於て はその点を明らかにし, 更に数種の analogues について, 解離の程度の比較検討を試みた.

\section{II. 対照並びに測定方法}

新潟大学西川内科に入院し, 諸種機能検査により確かめられた甲状腺機能低下症患者が選ばれた.

測定方法としては, BMR は Roth 法, PBI は Barker のアルカリ夷化法 ${ }^{4}$, 甲状腺 $\mathrm{I}^{131}$ 摂取率は科研製 scintillation-counter で24時間值が求められ, cholesterol は Schoenheimer-Sperry ${ }^{69}$ 法, phospholipids 及び

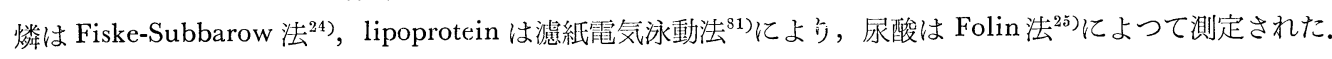

\section{III. 臨 床 結 果}

甲状腺機能低下症患者に L-thyroxine, L-triiodothyronine, D-triiodothyronine 及び $\mathrm{T}_{3}$-formic acid group の 4 種を，漸增法によつて微量より投与し，機能低下に対する治袮効果及び血清脂質低下作用とを観 察し，両作用の分離について検討し，更に一部の症例で尿酸及び燐代謝に及ぼす影響について検索した。

1. L-thyroxine (L-T $)$ の効果

症例 N. Y.（Fig. 1) では，L-thyroxine を微量より沽增的に経口投与された，治燎前值の平均は，血 清 cholesterol $310 \mathrm{mg} / 100 \mathrm{ml}$, phospholipids $250 \mathrm{mg} / 100 \mathrm{ml}, \mathrm{BMR}-34 \%$, PBI は1.4mcg/100ml 及び甲状腺 $\mathrm{I}^{131}$ 揕取率 $0 \%$ であつた。

L-thyroxine 1 日25mcg の投与で血清 cholesterol はわずかな変化をみたが，100 mcg以下の投与では有意な低下はみられな かつた. しかし1 日200mcg の投与で，血 清 cholesterol は233mg/100ml と治療前 值に比べて $25 \%$ の減少をきたした，血清 phospholipids も大体 cholesterol に一致 した態度を示した. BMR に対しては， L-thyroxine $100 \mathrm{mcg}$ 以下でもわずかな漸 增傾向が認められ，200mcg の投与でー19 \%を示し， $400 \mathrm{mcg}$ ではー9〜ー1\%と上 昇した. BMR の上昇に従つて一般症状の 改善も認められた。

血清 cholesterol と BMR との関係を みると, 投与量の增加に一致して, 両者は ほぼ同程度の態度を示しているように思わ れ，両作用の間には有意な解離傾向は認め られなかつた。

$\mathrm{PBI}$ は投与中止洔 $6.0 \mathrm{mcg} / 100 \mathrm{ml}$ と $\mathrm{BMR}$
Fig. 1. Effects of L-Thyroxine (L-T $\left.{ }_{4}\right)$ Idiopathic Myxedema N.Y. 44 F

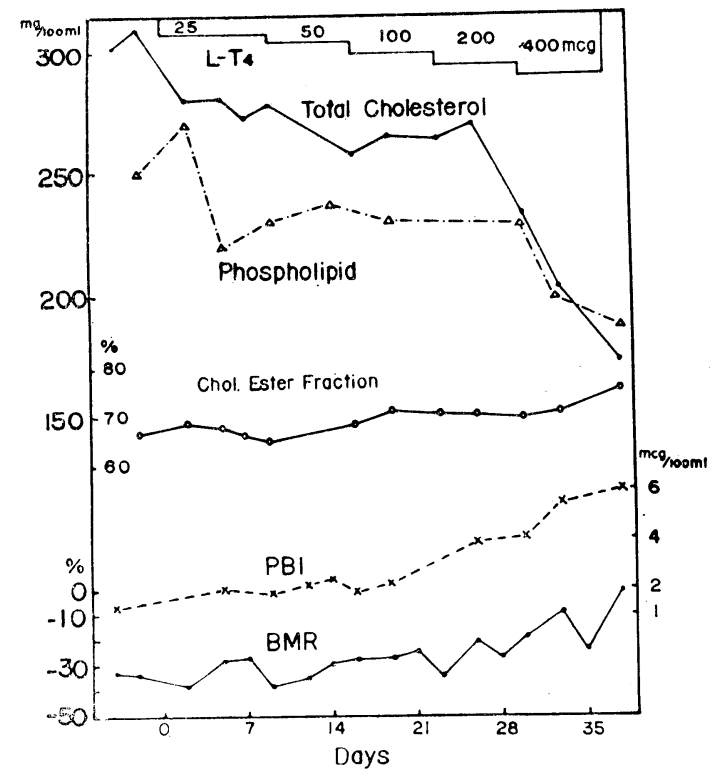

第38巻 第 9 号 
の正常になるに一致して正常値に復した.

\section{2. $3: 5: 3^{\prime}$-L-triiodothyronine (L-T $\left.{ }_{3}\right)$ の効果}

症例 M. S. (Fig. 2) は幼時より甲状腺機能低下症状を示し, cretinism として治療を受けていたが，服 薬の不規則により症状の増悪をみたので一時投薬を中止して，L-triiodothyronine を微量より投与した. 服 薬中止後33日で BMR はー26\%乃至一30 $\%$ PBI は $1.2 \mathrm{mcg} / 100 \mathrm{ml}$ 及び $\mathrm{I}^{131}$ 摂取率 は2.6\%を示し，血清 cholesterol は285mg /100ml であつた. この症例で血清 chole sterol 低下作用は，1 日約 $10 \mathrm{mcg} の$ Ltriiodothyronine の投与で現われ，15mcg 投与終了時には $214 \mathrm{mg} / 100 \mathrm{ml} と 25 \%$ の減 少をみた，BMR は $10 \mathrm{mcg}$ の投与で軽度 の変化をみたにすぎず， $15 \mathrm{mcg}$ の投与でも - $15 \%$ を越えることなく, BMR の変化に 対して cholesterol の低下作用が若干強い ようであるが，はつきりしたものでない． これについては, 症例 Y. K. (Fig. 3)で も確かめられた。 この症例では L-thyroxine に引き続いて L-triiodothyronine が 投与された。 やはり 1 日 $100 \mathrm{mcg}$ 以下の L -thyroxine では，血清 cholesterol に有 急な変化がみられず，BMR はー45\%より -25\%と軽度に上昇した。ここでBMR を 上昇させない程度の L-triiodothyronine 1 日 $12.5 \mathrm{mcg}$ 投与に切り換えた所 BMR は -20\%以下に維持できたにもかかわらず， 血清 cholesterol は急速に低下をきたした.

従つて前症例及び本症例より10万至 12.5 mcg 程度の L-triiodothyronine で, BMR 上昇作用と cholesterol 低下作用との間に 軽度の解離傾向が認められたが, 血清 cholesterol の低下は両症例とも，乙の程度の 投与量では持続できなかつた，25mcg で BMR は著明に上昇した。

前記 2 症例で L-triiodothyronine 投与 によつて PBI の上昇はみられなかつた。

\section{3. $3: 5: 3^{\prime}$-D-triiodothyronine (D-T ${ }_{3}$ ) の} 効果

症例 S. I. (Fig. 4) では D-triiodothyronine 1 日 $0.2 \mathrm{mg}$ より $0.6 \mathrm{mg}$ まで投与. された. 血清 cholesterol は0.2mgの投与 で既に $262 \mathrm{mg} / 100 \mathrm{ml}$ より $211 \mathrm{mg} / 100 \mathrm{ml}$ ま で低下し，0.4mg で $176 \mathrm{mg} / 100 \mathrm{ml}, 0.6 \mathrm{mg}$

Fig. 2. Effects of L-Triiodo-thyronine $\left(\mathrm{L}-\mathrm{T}_{3}\right)$ Cretinism M.S. 27 F

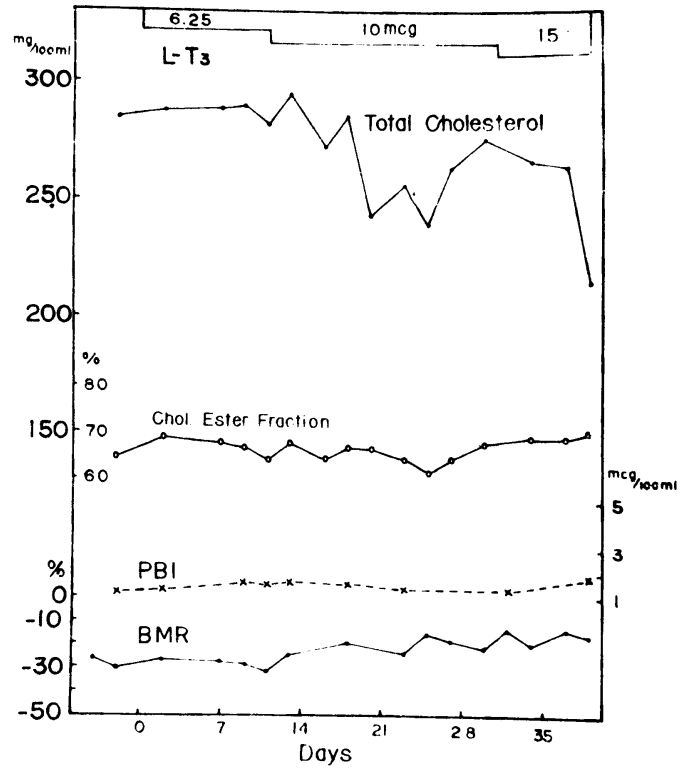

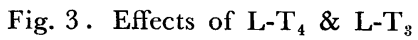
Idiopathic Myxedema Y.K. $17 \mathrm{~F}$

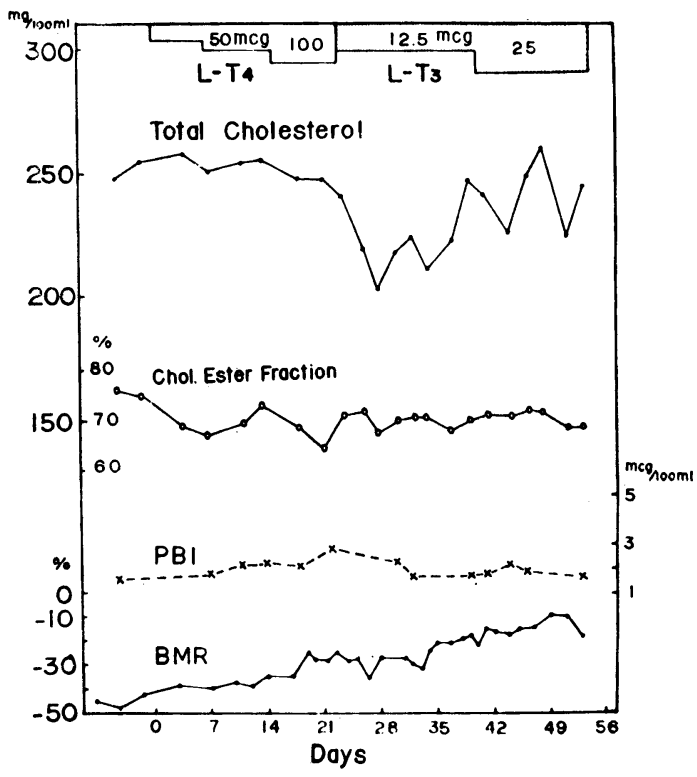

第38巻 第 9 号 
投与終了時には $164 \mathrm{mg} / 100 \mathrm{ml}$ と $37.4 \%$ の 減少をきたした。 phospholipids も cholesterol にほぼ平行して $207 \mathrm{mg} / 100 \mathrm{ml} よ り$ $122 \mathrm{mg} / 100 \mathrm{ml}$ 亿低下した.

それに反して BMR では，乙の投与量 で殆んど変化はみられなかつた。 PBI は D-triiodothyronine 投与開始の17日前まで $\mathrm{T}_{3}$-formic acid が投与されていたために， 治療開始時 $23 \mathrm{mcg} / 100 \mathrm{ml}$ であつたが，投 薬中減少を示し, 投与中止時 $8.2 \mathrm{mcg} / 100$ $\mathrm{ml}$ であつた. 従つて少なくともとの程度の D-triiodothyronine の投与では，著明な PBI の上昇はないものと思われる.

4. $3: 5: 3^{\prime}$-triiodothyroformic acid group ( $\mathrm{T}_{3}$-formic acid group) の効果

Fig. 5 に示される $\mathrm{T}_{3}$-formic acid ; acetyl $\mathrm{T}_{3}$-formic acid; $\mathrm{T}_{3}$-formic acid, methyl ester 及び $\mathrm{T}_{3}$-formic acid, amide の 4 種が使用された。

a. Triiodothyroformic acid ( $\mathrm{T}_{3}$-formic acid)
Fig. 4. Effects of D-T Idiopathic Myxedema S.I. 33 F

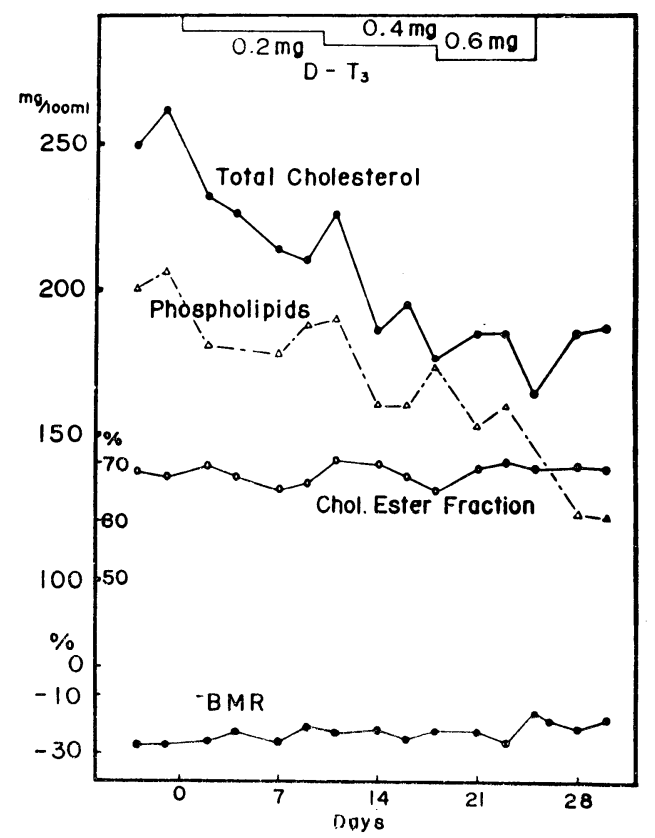

Fig. $5 \mathrm{~T}_{3}$-Formic Acid Group

\section{T3-Formic acid}

Acetyl T3-Formic ocid

Ts - Formic acid, amide

Ts - Formic acid, methyl ester
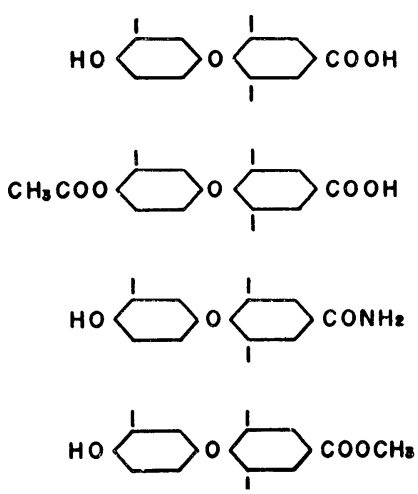

症例 S. I. (Fig. 6) 飞 $\mathrm{T}_{3}$-formic acid を 1 日 $4 \mathrm{mg}, 50 \mathrm{mg}$ 及び $100 \mathrm{mg}$ と12日間投与された. 血清 cholesterol の低下作用は，既に $4 \mathrm{mg}$ の投与で認められた. 治療前 $272 \mathrm{mg} / 100 \mathrm{ml}$ の血清 cholesterol は50 $\mathrm{mg}$ の投与で $200 \mathrm{mg} / 100 \mathrm{ml}$ と26.7\%の低下を示し，100mgの投与で $155 \mathrm{mg} / 100 \mathrm{ml} 26.7 \%$ 低下をきたした. それに対して BMR は $100 \mathrm{mg}$ の投与でも-29\%からー21\%に上昇したにすぎなかつた. PBI は投与量の増 加につれて著明に上昇し $100 \mathrm{mg}$ の投与では $160 \mathrm{mcg} / 100 \mathrm{ml}$ と異常な高值を示した.

b. Acetyl triiodothyroformic acid (acetyl $\mathrm{T}_{3}$-formic acid)

症例 H. O. (Fig. 7) は acetyl $\mathrm{T}_{3}$-formic acid を 1 日 $10 \mathrm{mg} よ り 100 \mathrm{mg}$ まで漸増的に38日間投与され た. 血清 cholesterol は投薬前 $279 \mathrm{mg} / 100 \mathrm{ml}$ あつたが， $10 \mathrm{mg}$ の投与で $204 \mathrm{mg} / 100 \mathrm{ml}$ と $26.9 \%$ 減少を 
きたし，增量に䢨つて血清 cholesterol の 低下も著明となり，30mg 投与で $154 \mathrm{mg} /$ $100 \mathrm{ml}$ と $55.2 \%$ 低下を示した.

それに対して BMR の変化はごく軽度 で，治裺前－21\%であつたものが $30 \mathrm{mg}$ 以 下の投与では，-15\%を越えるてとがなく， $50 \mathrm{mg}$ の投与でー $10.8 \% ， 100 \mathrm{mg}$ ではー6.5 乃至 $+6.3 \%$ を示し, $\mathrm{BMR}$ の上昇に一致 して臨床所見の改善が認められた。 PBI は 投与量の増加に一致して高值を示し，100 $\mathrm{mg}$ 投与終了時では $146 \mathrm{mcg} / 100 \mathrm{ml}$ と著时 に上昇した。

症例 I. S. (Fig. 8) にも acetyl Tyformic acid が投与された。 ての症例では 最初500mg の acetyl $\mathrm{T}_{3}$-formic acid を 3 回に分けて 1 日のみ投与され, その後臨 床効果の消失を待つて，1回投与の18日後 より連続投与が行なわれた。

投与前の各検查成績は, 血清 cholesterol $321.3 \mathrm{mg} / 100 \mathrm{ml}$, phospholipids $262.0 \mathrm{mg} /$ $100 \mathrm{ml}$, lipoprotein 比 $(\beta / \alpha) 4.23$, 血清 尿酸值 $3.76 \mathrm{mg} / 100 \mathrm{ml}$ ，尿中尿酸排泄量は 7 日の平均で $181.9 \mathrm{mg} / \mathrm{day}$, 燐の balance test ではやはり 7 日の平均で $+127.4 \mathrm{mg} /$ day, PBI $2.2 \mathrm{mcg} / 100 \mathrm{ml}, \mathrm{BMR}-18.5 \%$ 及 び $\mathrm{I}^{131}$ 蛽取率は $1 \%$ あ゙すた。

$500 \mathrm{mg} 1$ 回投与後の血清脂質は著明に低 下し, phospholipids は3日目に最低を示し $211 \mathrm{mg} / 100 \mathrm{ml}$ と $19.5 \%$ の低下，血清 cholesterol はそれに遅れて 8 日目に 196mg/ $100 \mathrm{ml}$ と最高 $39.0 \%$ の減少をみた. lipoprotein 比も 8 日目に最低值を示した。血中尿 酸值も投与 2 日後に減少をきたし，2.66mg $/ 100 \mathrm{ml}$ となり，尿中尿酸排泄量も 8 日間 の平均で $238.8 \mathrm{mg} /$ day と增加が認められ た. 又 $\mathrm{BMR}$ もこの投与量では翣日より 影響力涀われ，2 日後にはー- $\%$ に上昇し， PBI は投与翌日すでに最高值を示した。 連続投与に於ては, 所見はほぼ症例 $\mathrm{H}$. O、でみられたと同様で，血清 cholesterol は 1 日 $20 \mathrm{mg}$ の投与で $229 \mathrm{mg} / 100 \mathrm{ml}$ と 28.7 $\%$ \%低下をきたし，80mg では $167 \mathrm{mg} / 100$ $\mathrm{ml}$ と48.6\%の減少がみられた. phospho-
Fig. 6. Idiopathic Myxedema S.I. 33 F

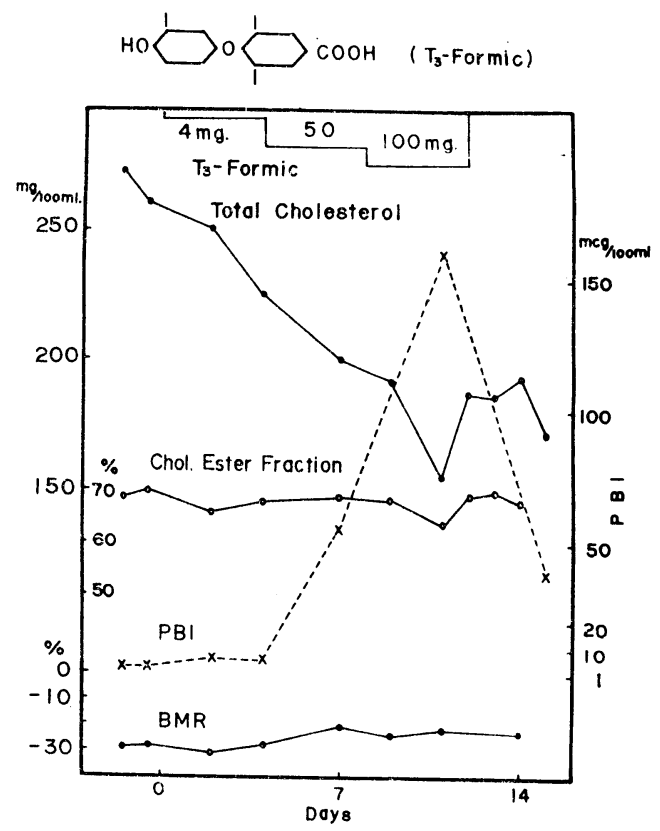

Fig. 7. Post-I ${ }^{131}$ Myxedema H.O. 31 F

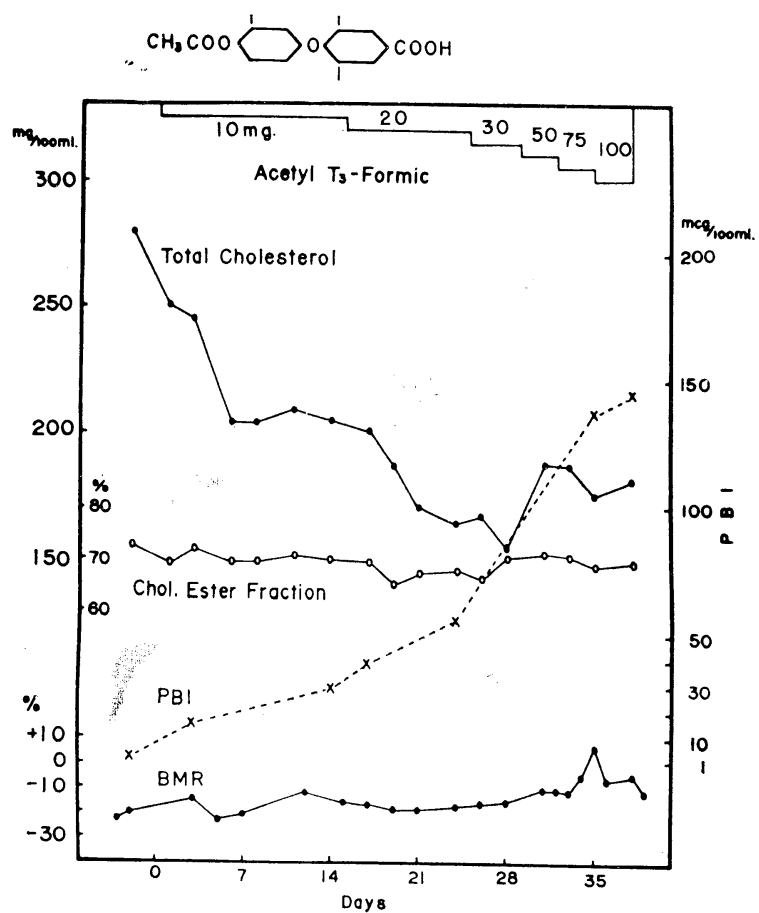

第38巻 第 9 号 
lipids はやはり $80 \mathrm{mg}$ で $183 \mathrm{mg} / 100 \mathrm{ml}$ と最 低值を示し， $\mathrm{C} / \mathrm{P}$ 比も 1.23 より 0.91 と低 下した. 更に血中永酸も投与中に3.00万至 $3.20 \mathrm{mg} / 100 \mathrm{ml}$ と低下傾向を示し, 燐の balance test でも投与後 22 日間の平均で $-3.6 \mathrm{mg} / \mathrm{day}$ と軽度の排泄増加傾向もみら れた.一方 $\mathrm{BMR}$ では 1 日 $40 \mathrm{mg}$ 以下の投 与では目立つた上昇は認められず, $80 \mathrm{mg} の$ 投与でー10万至 $+5 \%$ と正常化がみられた。 PBI はやはり投与量の增加につれて著明な 高值を示し， $80 \mathrm{mg}$ の投与で $169 \mathrm{mcg} / 100 \mathrm{ml}$ に上昇した。

症例 T. I. (Fig. 9) では, やはり acetyl $\mathrm{T}_{3}$-formic acid が投与された. acetyl $\mathrm{T}_{3}$-formic aicd $400 \mathrm{mg}$ を 1 日 3 回に分け て投与すると, phospholipids はやはり cholesterol の低下に先き立つて最低を示 し, $255.8 \mathrm{mg} / 100 \mathrm{ml}$ より $218 \mathrm{mg} / 100 \mathrm{ml}$ と 低下した，血清 cholesterol も治療前の平 均は $298.8 \mathrm{mg} / 100 \mathrm{ml}$ であつたが，投与 4 日目に $262 \mathrm{mg} / 100 \mathrm{ml}$ と $12.3 \%$ の減少をき たした．ての症例に於ては $400 \mathrm{mg} の 1$ 回投 与で BMR には影響がみられず，PBI は 投与梁日 $397 \mathrm{mcg} / 100 \mathrm{ml}$ と著明に上昇し た. 又燐の balance test で投与前 5 日の 平均は+184mg/day であつたが，投与後 11日の平均で $-32.3 \mathrm{mg} / \mathrm{day}$ と負の balance を示すようになり，特に投与翌日の総
Fig. 8. Idiopathic Myxedema I.S. $59 \mathrm{~F}$

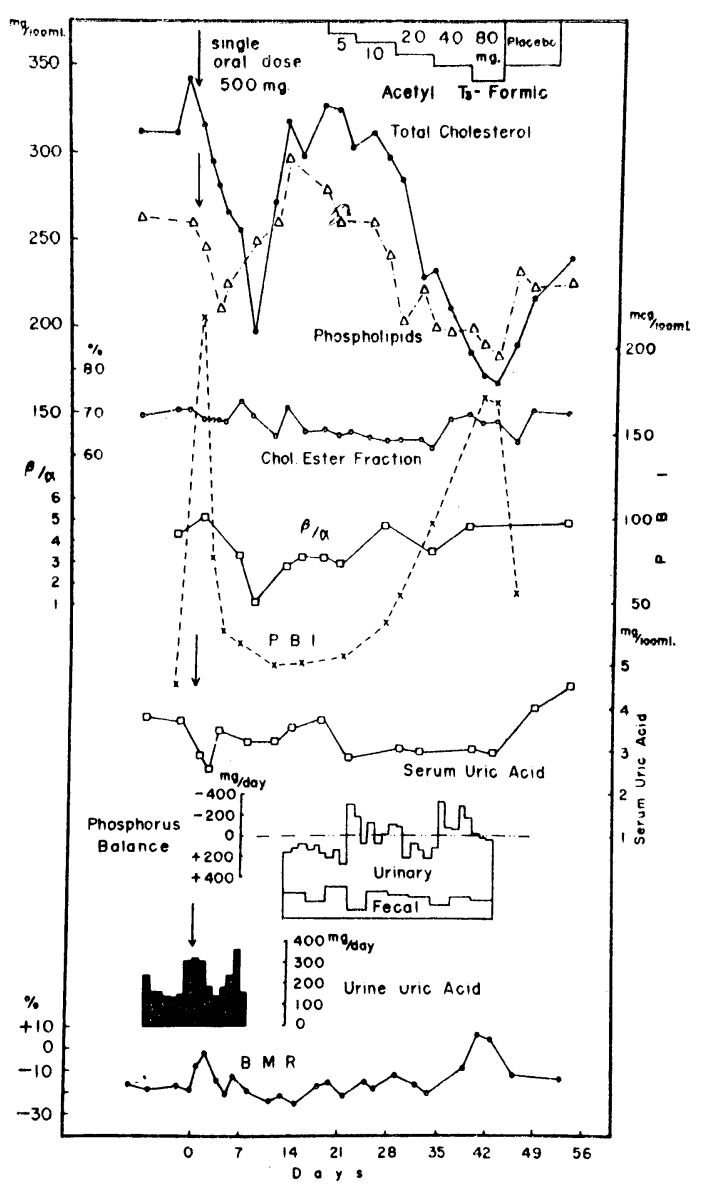

燐排泄量は $2283 \mathrm{mg} / \mathrm{day}$ と著明な増加がみられた。殊に尿中への排泄が著明であつた。

c. Triiodothyroformic acid, methyl ester ( $\mathrm{T}_{3}$-formic acid, methyl ester)

症例 H. T. (Fig.10) では $\mathrm{T}_{3}$-formic acid, methyl ester が投与された. 最初 $200 \mathrm{mg}$ を 3 回に分けて 1 日のみ投与され，その 7 日後より連続投与が行なわれた. 治療前の検查成績は, 血清 cholesterol $292.5 \mathrm{mg}$ $/ 100 \mathrm{ml}$, phospholipids $240.5 \mathrm{mg} / 100 \mathrm{ml}$, lipoprotein 比 5.79 , 血中尿酸值 $4.40 \mathrm{mg} / 100 \mathrm{ml}, 8$ 日間平均の尿 中尿酸排泄量は $666.5 \mathrm{mg} / \mathrm{day}$, 燐の balance test で前值の平均は $+254.0 \mathrm{mg} / \mathrm{day}, \mathrm{BMR}$ はー23.1\%, PBI か $2.2 \mathrm{mcg} / 100 \mathrm{ml}$ で，甲状腺 $\mathrm{I}^{131}$ 掑取率は $0 \%$ であつた。

1 回投与で血清脂質は投与当日すでに低下傾向が認められた。（Fig. 10に於て 1 回投与後の第 1 点は, 当日 の午後 4 時の採血による值である.) 血清 phospholipids は，てのものでも cholesterol に先き立つて投与 翌日 $199 \mathrm{mg} / 100 \mathrm{ml}$ と最低となり, lipoprotein 比も翌日に最低を示した. 血清 cholesterol は投与 3 日後 に $224 \mathrm{mg} / 100 \mathrm{ml}$ と $25 \%$ 減少がみられた。この症例で $200 \mathrm{mg} の 1$ 回投与では血中尿酸, 尿中尿酸排泄及び 燐の balance test に著明な変動は認められなかつた. BMR では投与後わずかな動摇があつたが，特に上 昇傾向は認められず，又 PBI は投与当日既に $37 \mathrm{mcg} / 100 \mathrm{ml}$ と最高值を示した.

連続投与では向清 cholesterol は漱次低下倾问を示し，50mg投守で $222 \mathrm{mg} / 100 \mathrm{ml}$ と26\%の減少をきたし， $100 \mathrm{mg}$ 投与洔 $216 \mathrm{mg} / 100 \mathrm{ml}$ となつた。一方 BMR に対しては $100 \mathrm{mg}$ 投与で 1 间一-6.3\%を示した以外は, 
Fig. 9. Post-I ${ }^{131}$ Myxedema T.I. 16 F

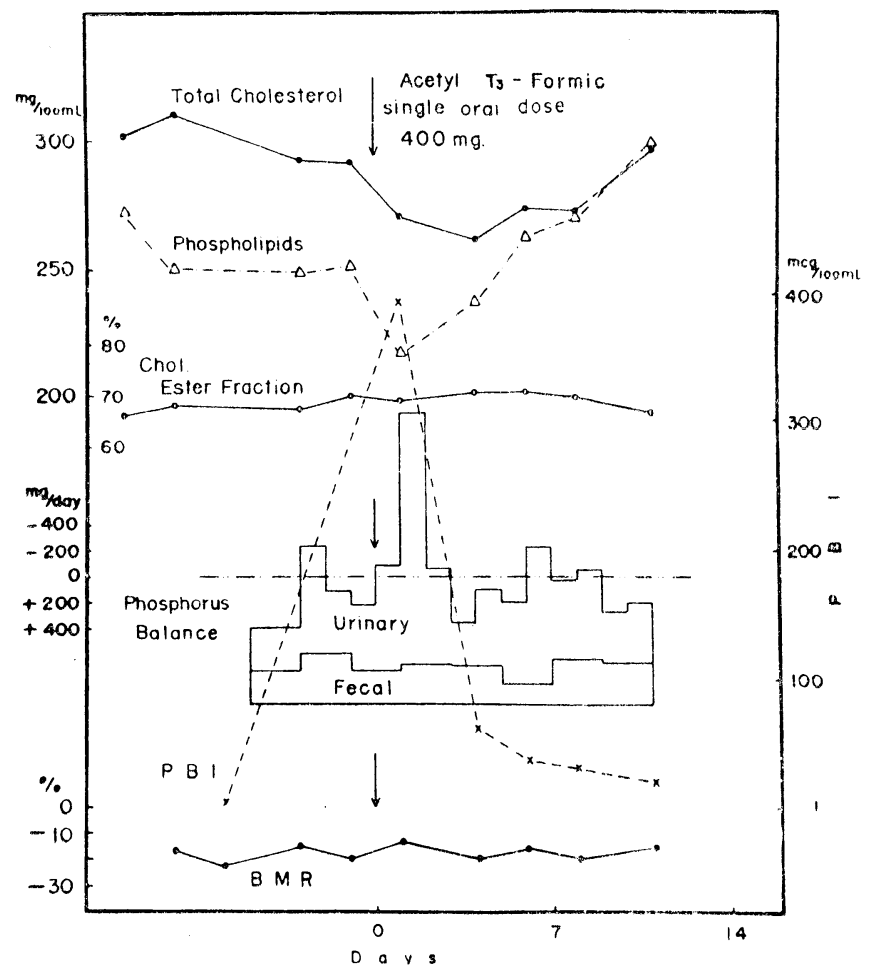

一18\%を越えることなく，乙の投与量以下では殆んど BMR に影響ないものと考えられた，又血中尿酸値 及び尿中尿酸排泄には特に著変はみられなかつたが，燐の balance test では連続投与の 29日間の平均で $-53.9 \mathrm{mg} / \mathrm{day}$ と燐排泄の増加傾向か認められた。 PBI は投与量の増加に従つて著明に上昇し, 投与中止 時 $119 \mathrm{mcg} / 100 \mathrm{ml}$ であつた.

d. Triiodothyroformic acid, amide ( $\mathrm{T}_{3}$-formic acid, amide)

症例 T. M. (Fig.11) には $\mathrm{T}_{3}$-formic acid の amide の形のものを $20 \mathrm{mg}$ まで投与された. 血清 cholesterol は 1 日 $5 \mathrm{mg}$ の投与で $273 \mathrm{mg} / 100 \mathrm{ml} り 233 \mathrm{mg} / 100 \mathrm{ml}$ に低下し， $10 \mathrm{mg}$ の投与では $208 \mathrm{mg} / 100 \mathrm{ml}$ ， $20 \mathrm{mg}$ で $196 \mathrm{mg} / 100 \mathrm{ml} 228 \%$ の減少がみられた。 phospholipids も cholesterol 亿平行して低下傾向を示し， $20 \mathrm{mg}$ 投与では $210 \mathrm{mg} / 100 \mathrm{ml}$ より $157 \mathrm{mg} / 100 \mathrm{ml}$ 亿低下した。.てれに対して BMR は 1 日 $20 \mathrm{mg}$ 以下の投与で はー22\%を越えることがなかつた。 PBI は投与終了時 $36 \mathrm{mcg} / 100 \mathrm{ml}$ に上昇した。

e. $T_{3}$-formic acid groupの血中消失速度

$\mathrm{T}_{3}$-formic acid group の各々について, 血中ょりの消失速度を, 投薬中止後の PBI の減衰より半減期と して求めると，Fig.12にみられる如く，投薬中止後の日数に対して，PBI の変動を対数グラフ上にとれば， ほぼ直線的な減䘚を示し，その半減期は， $\mathrm{T}_{3}$-formic acid で 2.9 日, acetyl $\mathrm{T}_{3}$-formic acid では2.0万至 2.4 日， $\mathrm{T}_{3}$-formic acid, methyl ester は4.5日であつたが, amide の形のものでは少し長くて 8.8 日であつた.

\section{IV. 考按並びに総括}

以前より, 甲状腺と脂質代謝との関係は, 臨床的及び実験的に確かめられて28)3955253359960), 又甲状腺機能低 下症患者を甲状腺末或は L-thyroxine や L-triiodothyronine 等で治療するととにより，BMR 及び臨床症

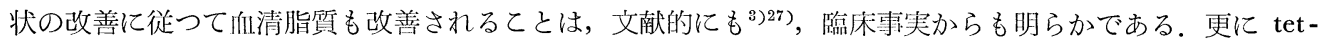


Fig. 10. Post-I ${ }^{131}$ Myxedema H.T. $36 \mathrm{M}$

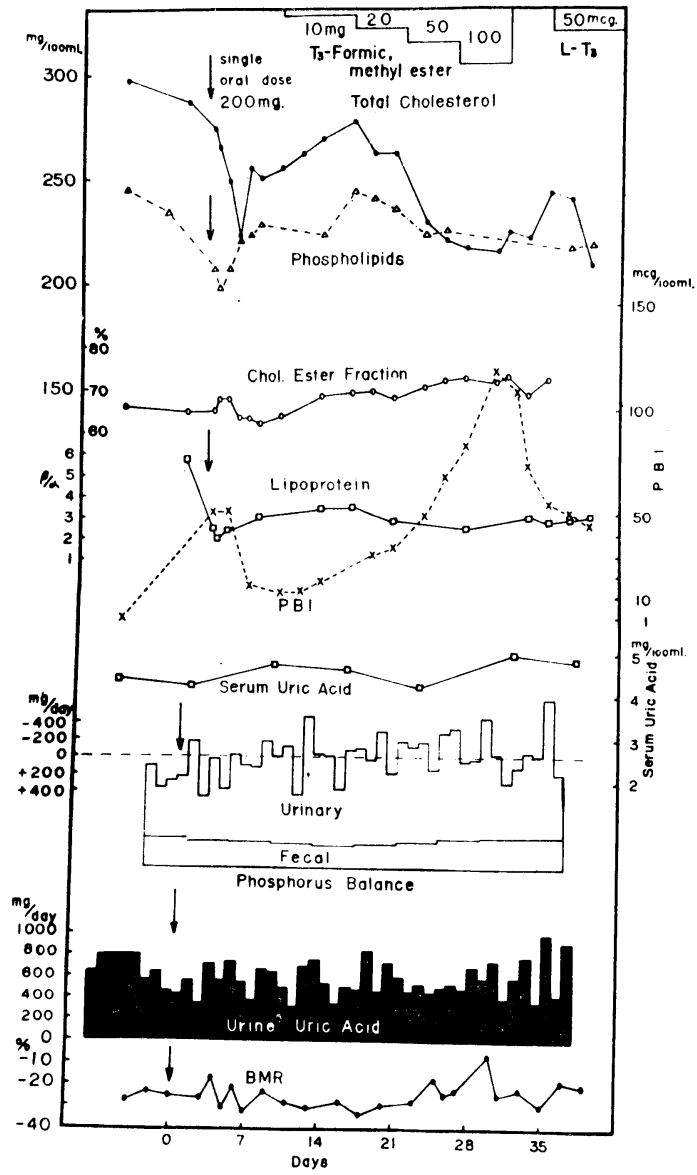

Fig. 11. Idiopathic Myxedema T.M. $40 \mathrm{~F}$

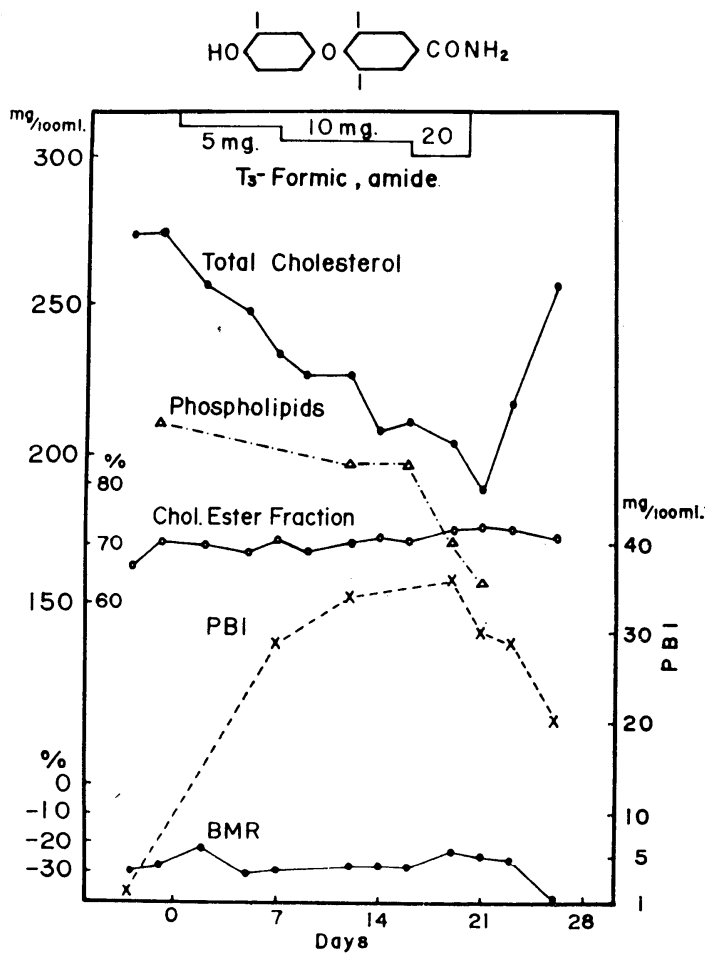

rac，triac の合成以来，乙れらの thyroxine analogues の血清脂質に対する作用が注目され，てれら analogues の或るものは calorigenic activity に対して比較的強い血清脂質低下作用のあるてとが報告されてい る.

\section{L-thyroxine 及び L-tviiodothyronine の作用の解離について}

しかし本来の hormone である L-thyroxine 及び L-triiodothyronine に於て，乙の calorigenic な作用 と血清脂質に対する作用とが，はたして平行的なものであるか否かを検討した報告は少なく,最近 Lerman ${ }^{48)}$ は乾燥甲状腺末を粘液水腫に投与し，その血清脂質低下作用及び，BMR 上昇作用は投与量に比例して変化 し，直線関係を示すのに反し，triac では直線関係が成り立たないととを報告しているにすぎない.

ここで L-thyroxine, L-triiodothyronine 及び acetyl $\mathrm{T}_{3}$-formic acid そついて, 粘液水腫患者の血清 cholesterol を治療前の $25 \%$ 低下させるととのできる誘導体の量を対比させてとり “BMR の上昇率（たと えばー30\%の BMR がー15\%になつた場合を $50 \%$ 上昇率とみなす)”と比較すると，Fig. 13 の如く，本来 の甲状腺 hormone である L-thyroxine 及び L-triiodothyronine では, 血清 cholesterol を25\%低下させ うる薬量範囲で直線関係が得られ，乙の範囲内で BMR は50\%の上昇率がみられた．ての点より L-thyroxine 及び L-triiodothyronine では BMR 又は cholesterol に対する作用の間に著明な解離傾向は認めら れなかつた。 但し L-triiodothyronine も 10mcg 以下では BMR に影響を与えずに cholesterol の低下傾 


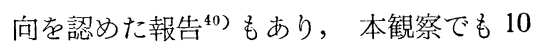
mcg でその傾向がうかがわれた.

粘液水腫患者に L-thyroxine を投与し た場合，血清 cholesterol は正常にまで低 下しうるが，その時には BMR 及び臨床症

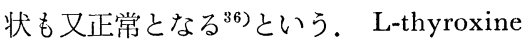
及び L-triiodothyronine の作用は BMR や cholesterol のみならず，窒素代謝，燐 代謝等に対しても効果を有し，しかも效果 発現の速さ及び効果の大きさに於て異なる のみで，質的差異はないといわれ $れ^{3 / 63) ， い ~}$ ずれにしてもこの両者で BMR は上昇作 用と血清 cholesterol 低下作用との間に著 明な解離傾向は認められない楒)。

てれに対して acetyl $\mathrm{T}_{3}$-formic acid は 大量ではほぼ直線関係が得られるが，投与 量の增加に比して BMR の変化が少なく 血清 cholesterol を25\%低下させうる程度 の投与量以下即ち $20 \mathrm{mg}$ 以下では, 直線関 係は得られず，BMR には殆んど影響ない か,でくわずかであつた. 即ち acetyl $\mathrm{T}_{3}$ -formic acid では比較的少量の投与で,

BMR 亿変化を与えずに血 清 cholesesrol の低下作用 が認められた。

このととから,各種 analogues について BMR の $50 \%$ 上昇率をきたす薬量, 及び血清 cholesterol t治 燎前の值より $25 \%$ 低下させ るに要する薬量とをみると Table 1 の如くである.

\section{Thyroxine analogues} の BMR 上昇作用

L-thyroxine では BMR の50\%上昇率をきたすのに 1 日約 100 万至 $200 \mathrm{mcg}$ を必 要とし，てれを $100 \%$ とし
Fig. 12. PBI-T1/2 of Thyroxine Analogue
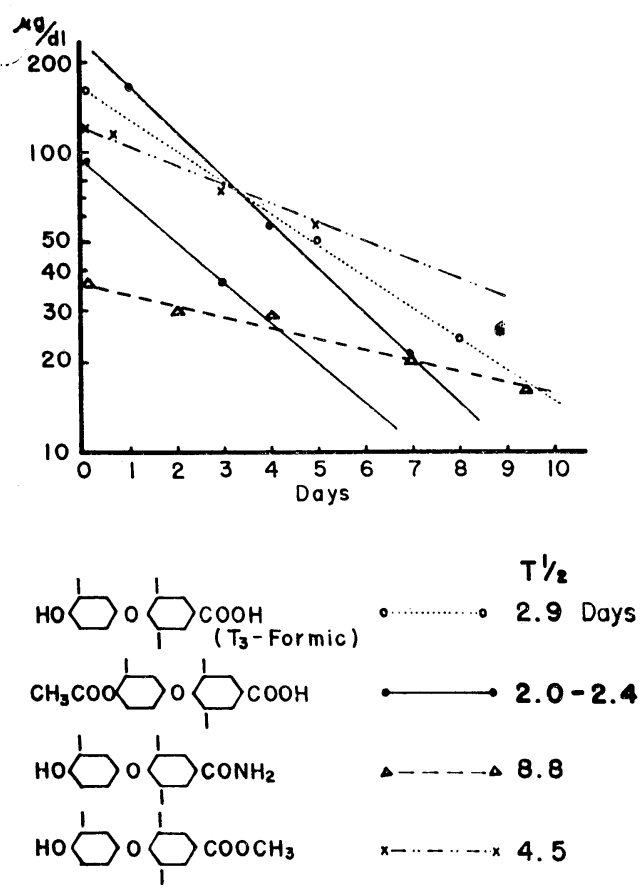

Fig. 13. Percentage Change of BMR in Myxedematous Patients Receiving Graded Dosage of Analogues

て各々の比較的活性度をみると, Table1でみられるように, D-thyroxine は BRM に対して L-thyroxine の 3 乃至 $10 \%$ の価を有する。乙れは粘液水腫患者に於ける他の報告の $2 \sim 10 \%{ }^{8) 10}$ に一致する.

L-triiodothyronine は粘液水腫患者の BMR に対しては L-thyroxine の400〜800\% $\%^{38)}$ ) といわれている が，木研究に於ては400〜1300\%である。

D-triiodothyronine, tetrac 及び triac については，それでれ17〜33\%より大，2.5〜6.7\%及び3.3〜10\% 第38巻 第 9 号 
Table 1. Appoximate Minimal Daily Dose of Thyroactive Compounds Required to Reduce Serum Cholesterol \& Raise BMR in Hypothyroid Patients

\begin{tabular}{|c|c|c|c|c|c|}
\hline Thyroactive & \multicolumn{2}{|c|}{$\begin{array}{l}50 \% \text { Increase in } \\
\mathrm{BMR}\end{array}$} & \multicolumn{2}{|c|}{$\begin{array}{l}25 \% \text { Depression in } \\
\text { Serum Cholesterol }\end{array}$} & \multirow{2}{*}{$\begin{array}{l}\text { BMR/Chol } \\
\text { Ratio }\end{array}$} \\
\hline Compound & Dose & $\begin{array}{l}\text { Relative } \\
\text { Potency }\end{array}$ & Dose & $\begin{array}{l}\text { Relative } \\
\text { Potency }\end{array}$ & \\
\hline $\mathrm{L}-\mathrm{T}_{4}$ & $100-200 \mathrm{mcg}$ & 100 & $200-400 \mathrm{mcg}$ & 100 & $0.25-1$ \\
\hline $\mathrm{D}-\mathrm{T}_{4}$ & $2-3 \mathrm{mg}^{\mathrm{a}}$ & $3-10$ & $\stackrel{\text { under }}{1-2 \mathrm{mg}}$ & $>10-40$ & $>1-3$ \\
\hline $\mathrm{L}-\mathrm{T}_{3}$ & $15-25 \mathrm{mcg}$ & $<400-1300$ & $10-25 \mathrm{mcg}$ & $800-4000$ & $0.6-2.5$ \\
\hline $\mathrm{D}-\mathrm{T}_{3}$ & $\begin{array}{l}\text { over } \\
600 \mathrm{mcg}\end{array}$ & $<17-33$ & $400 \mathrm{mcg}$ & $50-100$ & $>1.5$ \\
\hline Tetrac & $3-4 \mathrm{mg}^{\mathrm{a}}$ & $2.5-6.7$ & $2-4 \mathrm{mg}^{\mathrm{a}}$ & $5.0-20$ & $0.75-2$ \\
\hline Triac & $2-3 \mathrm{mg}{ }^{\mathrm{a}}$ & $3.3-10$ & $1-2 \mathrm{mg}^{\mathrm{a}}$ & $10-40$ & $1-3$ \\
\hline$\left(\mathrm{T}_{3}-\mathrm{Fo}\right.$ & $\begin{array}{l}\text { over } \\
\qquad 100 \mathrm{mg}\end{array}$ & $\ll 0.1-0.2$ & $50 \mathrm{mg}$ & $0.4-0.8$ & $? \gg 2$ \\
\hline & $50-75 \mathrm{mg}$ & $0.1-0.4$ & $10-20 \mathrm{mg}$ & $1-4$ & $2.5-7.5$ \\
\hline & $\begin{array}{l}\text { over } \\
20 \mathrm{mg} \\
\text { (no change) }\end{array}$ & $\ll 0.5-1$ & $20 \mathrm{mg}$ & $1-2 i$ & $? \gg 1$ \\
\hline & $\begin{array}{l}\text { over } \\
\qquad 100 \mathrm{mg}\end{array}$ & $\ll 0.1-0.2$ & $50 \mathrm{mg}$ & $0.4-0.8$ & $? \gg 2$ \\
\hline & $\begin{aligned} \text { under } & \text { a } \\
2 \mathrm{mg} & \end{aligned}$ & & $\begin{array}{r}\text { under } \\
2 \mathrm{mg}\end{array}$ & & \\
\hline$\left(\mathrm{T}_{3}-\mathrm{P}\right.$ & & & & & \\
\hline
\end{tabular}

a：田村 ${ }^{82)}$ とるる

と他の報告 $\left.\left.{ }^{8) 38}\right)^{50}\right)$ にほぼ一致する。

現在までの所， $\mathrm{T}_{3}$-formic acid group の粘液水腫患者に対する効果についての報告は見受けられない。 $\mathrm{T}_{3}$-formic acid は rat で BMR 上昇作用はない ${ }^{855}$ といわれていたが，粘液水腫患者に対しては BMR上 昇作用が認められた，しかしその作用は極めて弱く，BMR の50\%上昇率をきたすには，acetyl $\mathrm{T}_{3}$-formic 
acid で1 日50〜75mgを必要とし，L-thyroxine の0.1〜0.4\%の作用しか有しない. $\mathrm{T}_{3}$-formic acid 及び $\mathrm{T}_{3}$-formic acid, methyl ester では，それぞれ100mgまで使用されたが，BMR は50\%の上昇率をきたさな かつた. しかし $\mathrm{T}_{3}$-formic acid 100mg の投与で BMR は-29\%よりー21.3\%とわずかな上昇を示し， $\mathrm{T}_{3}$ formic acid, methyl ester でも-23\%よりー18\%とわずかな上昇傾向が認められた. $\mathrm{T}_{3}$-formic acid, amide は20mgまで投与されたが BMR には変動がみられなかつた. 従つて $\mathrm{T}_{3}$-formic acid; $\mathrm{T}_{3}$-formic acid, amide 及び methyl ester は BMR に対して，L-thyroxine のそれぞれ0.1〜0.2\%，0.5〜 1\%及び0.1〜0.2 \%より更に小さな効果を有するに過ぎないと思われる.

一般に thyroxine analogues の作用はいかなる assay に於ても，一つの compound group についてみ ると, $3: 5: 3^{\prime}$-triiodo-analogues, 3:5:3' $: 5^{\prime}$-tetraiodo-analogues 及び 3:5-diiodo-analogues の順に活 性度が弱くなり ${ }^{1120) 22773}$, D-isomer は L-isomer よりも弱(11)18)とされ, 又 amino acid side chain を propionic acid, acetic acid 及び formic acid におきかえると，やはりての順に活性度が低下する ${ }^{18)}$ とい われる．以上の傾向は Table 1 で粘液水腫に於ける BMR 並びに cholesterol に対する作用についても認め られる. Formic acid group は rat の酸素消費量を増加させる作用は L-thyroxine の $3 \%$ 以下 ${ }^{73}$ で3: $5:$ $3^{\prime} ; 5^{\prime}$-tetraiodothyroformic acid ( $\mathrm{T}_{4}$-formic acid) は粘液水腫患者の BMR 上昇作用は L-thyroxine の $0.12 \%{ }^{8)}$ であるという.

\section{Thyroxine analogues の BMR 上昇作用と血清 cholesterol 低下作用との解離}

L-thyroxine 及び L-triiodothyronine に関しては先に述べたが，Fig.13にみられた如く acetyl $\mathrm{T}_{3}$-formic acid では BMR 上昇作用と血清 cholesterol 低下作用との間に解離のあることは明らかである。乙の 解離の程度は analogues により差があり, Table 1 亿於て BMR の50\%上昇率をきたす薬量と, cholesterol を25\%低下させるに必要な投与量との比をみると，L-thyroxine では $0.25 〜 1$ ，及び L-triiodothyronine では0.6〜2.5であるのに対し，D-thyroxine は 1〜3より大きく，D-triiodothyronine では1.5より大 で, acetyl $\mathrm{T}_{3}$-formic acid は2.5〜7.5並びに $\mathrm{T}_{3}$ formic acid, $\mathrm{T}_{3}$-formic acid, amide 及び methyl ester はそれぞれ $2 ， 1$ 及び 2 より更に大きな值を示している。この值の大きいととは解離の程度の大きいととを 示していることになる. D-thyroxine 及び $\mathrm{T}_{3}$-formic acid group は cholesterol 低下作用の比較的強い 物質と考えられる。粘液水腫患者に BMR を上昇させない程度の投与量で，血清脂質又は Cholesterol を

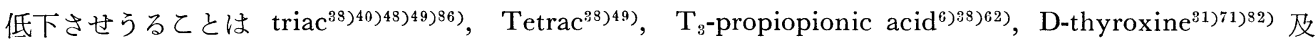

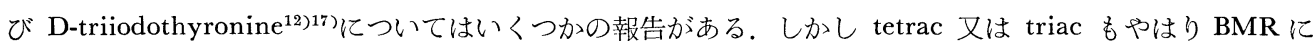
対して影響が現われやすく ${ }^{66)}$ ， Table 1 に於ても D-thyroxine や $\mathrm{T}_{3}$-formic acid group よりも， BMR に対していくらか大きな影響のあるてとが知られる。

$\mathrm{T}_{4}$-formic acid そついては粘液水腫患者及び高 cholesterol 血症患者に投与された報告もあり，20 mg まででは，BMR 及び cholesterol の両者に影響がない(8) といわれていたが，Boyd and Oliver $\left.{ }^{12}{ }^{19}\right)$ は， $\mathrm{T}_{4}$-formic acid は粘液水腫患者では 1 日 $100 \mathrm{mg}$, 甲状腺機能正常者では200乃至 $300 \mathrm{mg}$ で血清 cholesterol の低下がみられ，乙の程度の投与量で BMR に変化がみられなかつたととを記載し，一方 Best and Duncan ${ }^{8}$ によれば, 粘液水腫患者の BMR を正常とするのに 1 日 $220 \mathrm{mg}$ を必要とするといわれている.

$\mathrm{T}_{3}$-formic acid group では, 粘液水腫に於ける解離傾向についても報告はみられず, 本研究で他の ana logues に比して血清 cholesterol に対する作用が一首強いことは注目に值する.

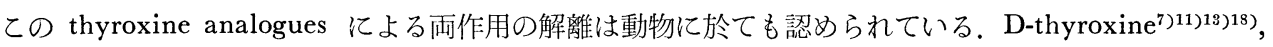

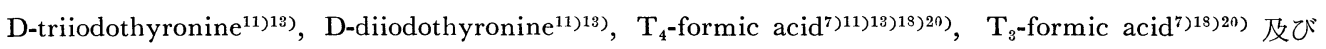
3 : 5-diiod-othyroacetic acid (diac) ${ }^{65) 66)}$ 等は他の analogues に比べて，BMR 又は心蔵に対する作用より も血清及び肝 cholesterol に対する作用が強いといわれている.

この様な analogues による作用の解離が，いかなる機序によるものかは, 現在の所明らかではない. 最 近 $\mathrm{I}^{131}$ 標示の thyroxine analogues を使用し, 生体内の分布を調べた実験から L-thyroxine 及び L-triiodothyronine は，血中，骨骼筋及び脳に比較的高濃度に分配され， propionic acid group 及び acetic acid 
group はそれらに比べて血中及び心筋に多く集まり，又血中よりの消失がおそい ${ }^{37}$. D-thyroxine は Lthyroxine に比べて肝や腎に多く集まり ${ }^{83}$ ， D-triiodothyronine も肝に多く集まる21)といわれ，従つて肝 cholesterol 飞強く作用するのかも知れないと想像されている. 又血中 cholesterol は肝機能により調節さ れる $\left.{ }^{29}\right)$ とわれており， cholesterol 代謝には，組織への分布の相異が関与していると考えられる，又，か かる作用の分離は BMR と cholesterol に対する作用の間にのみみられる現象ではない. ratの thiouracil 投与による甲状腺腫を同程度に抑制する量で比べると $\mathrm{T}_{4}$-formic acid 及び $\mathrm{T}_{3}$-formic acid は L-thyroxine よりも血中又は肝 cholesterol を低下させる作用の強いことが知られており ${ }^{20)}$ ，甲状腺腫予防効果も酸 素消費に対する効果と平行せず73)，甲状腺 $\mathrm{I}^{131}$ 摂取率の抑制効果70) も甲状腺腫予防やオタマジャクシの变態 に及ぼす効果とは一致する傾向なく，更に移植可能な下垂体腫瘍発生の抑制効果 ${ }^{62}$ も他の効果に平行しない といわれている。

\section{Thyroxine analogues の燐及び尿酸代謝に及ぼす影響}

乾燥甲状腺又は D.L-thyroxine の投与で，粘液水腫患者の尿中窒素排泄量の増加することは古くより知 られており，てとに ammonia $\mathrm{N}$, uric acid $\mathrm{N}$ 及び creatin $\mathrm{N}$ の排泄が増加する ${ }^{14)(9)}$. 窒素代謝のみなら ず燐代謝に対しても L-thyroxine 及び L-triiodothyronine ${ }^{3)}$, tetrac 及び $\operatorname{triac}^{40) 50)}$ 並びに $\mathrm{T}_{3}$-propionic acid $^{6)}$ が効果を有すると考えられている.

一方痛風患者の約 $30 \%$ 凤状腺の機能低下が認められ ${ }^{46)}$, 又粘液水腫患者の或るものでは血清尿酸值高く, 尿中尿酸の排泄が低下しているといわれて7)，尿酸代謝と甲状腺機能との間に或る程度の関係がうかがわれる。 粘液水腫患者の高尿酸血症は適当の乾燥甲状腺 ${ }^{62)}$, L-triiodothyronine ${ }^{47}$ 及び $\mathrm{T}_{3}$-Propionic acid ${ }^{637)}$ の投 与で低下が認められている。Fig. 8 の症例 I. S. 及びFig.10の症例 H. T. では血清尿酸值は高值をとつて おらず， $T_{3}$-formic acid, amide 投与例では血中尿酸值又は尿中尿酸排泄量に変動が認められなかつたが， acetyl $\mathrm{T}_{3}$-formic acid 投与例では血中尿酸值は 1 回の大量投与及び連続投与でも低下傾向を示し，尿中尿酸 排泄量も 1 回投与でわずかながら増加傾向 を示した。

この尿酸代謝に対する効果は，Fig. 14 亿 示された痛風の 1 例 J. T. でも確かめら れた. 治療前の血清尿酸值は $10.4 \mathrm{mg} / 100$ $\mathrm{ml}$ 䯩值をとり, D-triiodorthyronine をl 日0.2万至 $1.0 \mathrm{mg}$ を 9 日，その後は $\mathrm{T}_{3}$-pro pionic acid を $4 \mathrm{mg}$ 投与された。 D-triiodothyronine の投与で尿中尿酸排泄増加 と血中尿酸值の低下をきたし， $\mathrm{T}_{3}$-propionic acid 投与でもその傾向が明らかで Benesid 投与に先立つて血中尿酸值は $4.85 \mathrm{mg}$ $/ 100 \mathrm{ml}$ と正常值を示し，3 ケ月以上にわ たり低值を維持できた。

この尿中尿酸排泄増加及び血中尿酸值の 低下は，analogues の投与により婜血流量 が増し ${ }^{47)}$, 尿酸の clearance が増加するた め的といわる。

燐の代謝については, Rawson $\left.{ }^{63}\right)$ は燐の総 排泄量の増加と共に血中燐值の上昇も認め られたことから婜機能のみより説明されな いとし, 粘液水腫のいわゆる唄蔵蛋白は大

Fig. 14. Effects of D-T $\mathrm{T}_{3} \& \mathrm{~T}_{3}$-Prop.

Gout J.T. $56 \mathrm{M}$

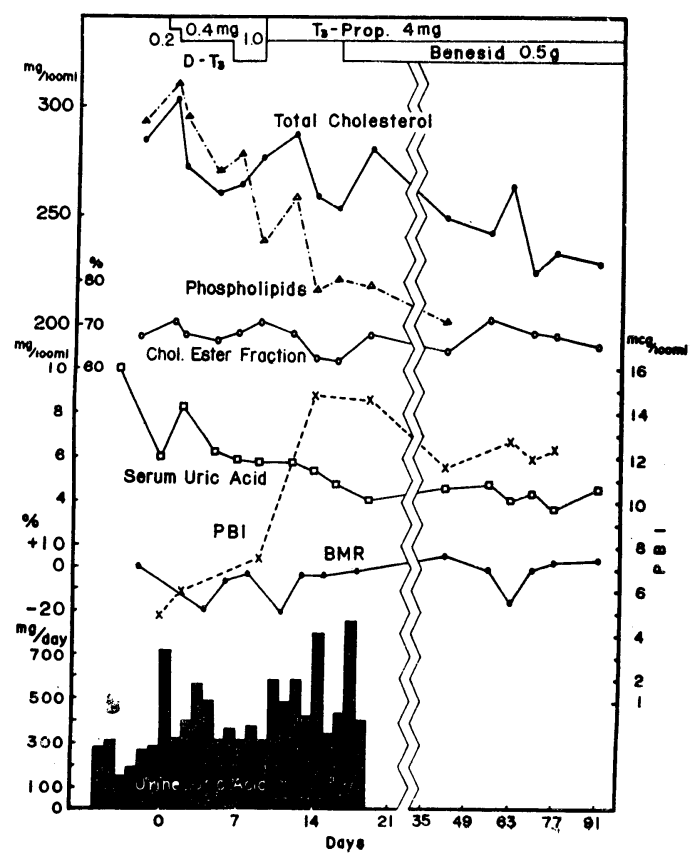

第38巻 第 9 号 
量の燐を含有しているか，或は phospholipids から遊離した燐が考光られると述べている．

一般に甲状腺機能低下で腎機能はいずれも低下を示し, thyroid hormone の投与で GFR 又は RPFょ

りも TmPAH の上昇が著明で, 従つて thyroid hormone が腎に直接作用するものと考元わている ${ }^{26)}$.

5. Thyroxine analogues $の$ 血中消失速度

Thyroxine analogues の血中よりの消失速度は, 蛋白との結合能力 $\left.{ }^{64) 84}\right)$ 及び脱ヨード化によつて支配さ れると考えられる。 PBI 半減期は Benua, Leeper, Kumaoka and Rawson $\left.{ }^{6}\right)$ とれば，L-thyroxine では6.5日 であり, L-triiodothyronine, triac 及び $\mathrm{T}_{3}$-propionic acid は 2 乃至 3 日で， $\mathrm{I}^{131}$ 標示の L-thyroxine の半 減期 6 乃至12日，L-triiodothyronine の2.5日(3)，及び Sterling ${ }^{75) 76)}$ の結果にほぼ一致するという。

$\mathrm{T}_{3}$-formic acid 及び acetyl $\mathrm{T}_{3}$-formic acid は凡そ L-triiothyronine と同程度に速かに血中より消失し， $\mathrm{T}_{\mathrm{g}}$-formic acid, methyl ester はややおそく, amide の形のものでは L-thyroxine とほぼ同様の消失速度 であつた。

\section{V. 結 論}

甲状腺機能低下症患者に L-thyroxine，L-triiodothyronine，D-triiodothyronine 及び $\mathrm{T}_{\mathrm{g}}$-formic acid group の 4 種を投与し，更に 1 例の痛風患者に D-triiodothyronine 及び $\mathrm{T}_{3}$-propionic acid が投与された。

1. L-thyroxine 及び L-triiodothyronine では BMR 上昇作用と血清 cholesterol 低下作用との間に著 明な解離傾向は認められなかつた。

2. D-triiodothyronine は L-thyroxine の17〜33\%の BMR 上昇作用を有している.

Acetyl $\mathrm{T}_{3}$-formic acid は BMR に対しては, L-thyroxine の0.1〜0.4\%の効果しかなく， $\mathrm{T}_{3}$-formic acid ; $T_{3}$-formic acid, amide; 及び methyl ester は，それぞれ0.1〜0.2\%, 0.5〜1\%及び0.1〜0.2\%より 更に小さな効果を有するに過ぎない.

3. D-triiodothyronine 及び $\mathrm{T}_{3}$-formic acid group では BMR に対するよりも血清 cholesterol に対 する効果が強力と思われる。中でも $\mathrm{T}_{\mathrm{s}}$-formic acid group でての解離は著明であつた.

4. Acetyl $\mathrm{T}_{3}$-formic acịd で血中尿酸低下，尿中尿酸排泄增加及び燐の総排泄増加傾向が認められ， $\mathrm{T}_{8}$ formic acid, amide でも燐の総排泄増加傾向が確かめられた。

更に 1 例の痛風患者で D-triiodothyronine 及び $\mathrm{T}_{3}$-propionic acid の投与で血中尿酸低下と尿中尿酸排 泄增加傾向が 3 ケ月にわたり観察された.

5. PBI 半减期による血中よりの消失速度は, $\mathrm{T}_{3}$-formic acid は2.9日, acetyl $\mathrm{T}_{\mathrm{g}}$-formic acid は2.0〜 2.4日， $\mathrm{T}_{3}$-formic acid, amide では8.8日で, methyl ester は4.5日であつた。

第 2 編 甲状腺機能正常者に於ける D-thyroxine 及び acetyl

$\mathrm{T}_{3}$-formic acid の血清脂質低下作用

$$
\text { I. 緒言 }
$$

Atherosclerosis の傾向にある人が，しばしば血中 cholesterol の上昇のあるてと ${ }^{19)}$ が認められて以来， 血中又は組織の cholesterol を下げるような物質を見出すととが重要視されてきた。

乾燥甲状腺や thyroxine 投与で甲状腺機能低下症又は機能正常者の上昇せる血中 cholesterol を下げる ことはできるが，全体の代謝に及ぼす影響のために，atherosclerosis の治療剤として臨床的に使用すること はできない，

それで BMR，発育等に影響を与光るととなく， cholesterol を低下させうるような thyroxine analogues を見出す努力がなされてきている。

臨床的に thyroxine analogues を高 cholesterol 患者に使用するには，次のような作用のないととが望 
ましい.

1) Calorigenic effectの少ないとと

2) 発育に対しての作用がなく, 又体重減少をきたさないてと。

3 ）心臟に影響のないとと，もしくは狄心症を增覀させるような作用のないてと.

4 ) 効果に escape のないとと.

等である。

第 1 編の粘液水腫患者に於ける観察で，BMR 上昇作用に比べて，血清 cholesterol 低下作用の比較的強 いと思われた D-thyroxine 及び acetyl $\mathrm{T}_{3}$-formic acid を甲状腺機能正常の hypercholesterolemia の血 清脂質を低下させる目的で使用した。本編ておいてはその結果をのべる.

\section{II． 対照並びに測定方法}

各々10例の甲状腺機能正常者に D-thyroxine 又は acetyl $\mathrm{T}_{3}$-formic acid が投与された。 D-thyroxine 投与例は全例入院患者であり, acetyl $\mathrm{T}_{3}$-formic acid 投与例は 2 例を除き, 入院で 1 万至 2 ケ月間観察さ れ，その後外来で経過が追われた。測定方法は第 1 編に於けると同様である.

\section{D-thyroxine の血清脂質低下作用}

10例の甲状腺機能正常者に D-thyroxine を最初 1 日 $2 \mathrm{mg}$, 次いで $4 \mathrm{mg}$ を 3 乃至 6 週間にわたり投与し た.

Fig.15に示された症例 T. S. は，治療前の血清 cholesterol は $248 \mathrm{mg} / 100 \mathrm{ml}$ であつた. D-thyroxine 1 日 $2 \mathrm{mg}$ の投与で cholesterol は 6 日目に $229 \mathrm{mg} / 100 \mathrm{ml}$ とわずかに低下したが，その後はかえつて上昇を きたし，14日目には $283 \mathrm{mg} / 100 \mathrm{ml}$ となつた。 それで 1 日 $4 \mathrm{mg}$ に増量した所, 血清 cholesterol は最低167 $\mathrm{mg} / 100 \mathrm{ml}$ と33\%の減少をみたが，その後投与継続中に escape がみられ，治䝤前值にもどつた，血清 phospholipids も cholesterol とほぼ同様な 態度を示した。 BMR は治療前 $+10 \%$ で, $2 \mathrm{mg}$ の投与で殆んど変化はなかつたが, $4 \mathrm{mg}$ の投与で+30\%と軽度に上昇した. 血清 PBI 值は $3.4 \mathrm{mcg} / 100 \mathrm{ml}$ より投与中 止時には $10.0 \mathrm{mcg} / 100 \mathrm{ml}$ と軽度の上昇をき たし，甲状腺 $\mathrm{I}^{131}$ 椇取率は $4.2 \%$ と著明に 抑制された。 ての症例は冠不全の患者で時 々胸痛を訴えていたが，投与後にも自覚的 増悪はみられず, ECG で Tv5.6が一時増 增高を示したが投与継続中に又平低となつ た.

Fig.16 I 及びIIにみられるように D-thyroxine の投与された10例の甲状腺機能正 常者では 1 日 $2 \mathrm{mg}$ を 1 乃至 3 週間投与さ れた場合, 血清 cholestesterol は 1 例を除 いて低下をみたが，その中 5 例に escape がみられた。次いで $4 \mathrm{mg}$ を 1 刀至 3 週間 投与すると， $2 \mathrm{mg}$ で低下を示さなかつた 症例及び escape をみた症例も，共に低下 をきたしたが，中には殆んど変化のみられ

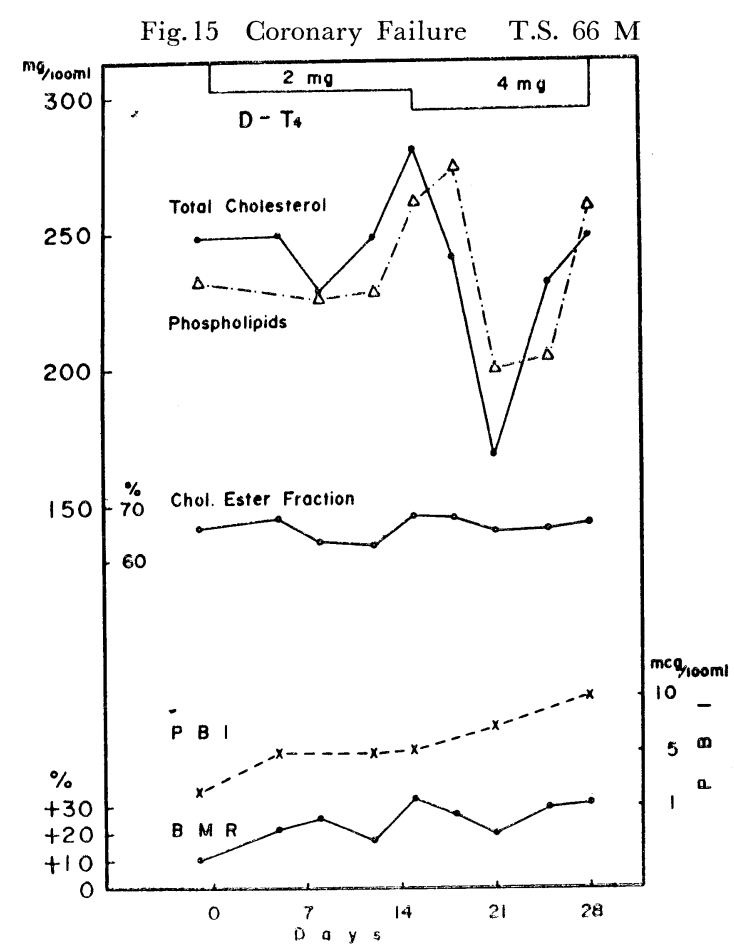

第38巻 第 9 号 
Fig. 16.

Effect of $\mathrm{D}^{-\mathrm{T}_{4}}$ on Serum Cholesterol Level of Euthyroid Patients I

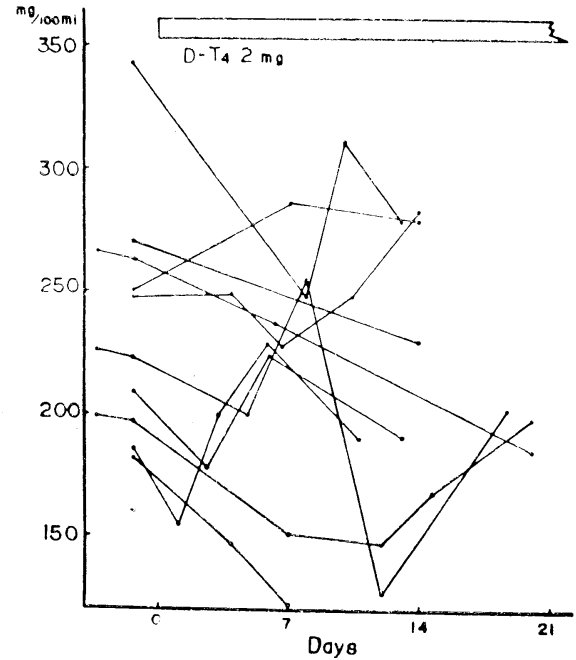

Effects of $\mathrm{D}^{-} \mathrm{T}_{4}$ on Serum Cholesterol

Level of Euthyroid Patients II

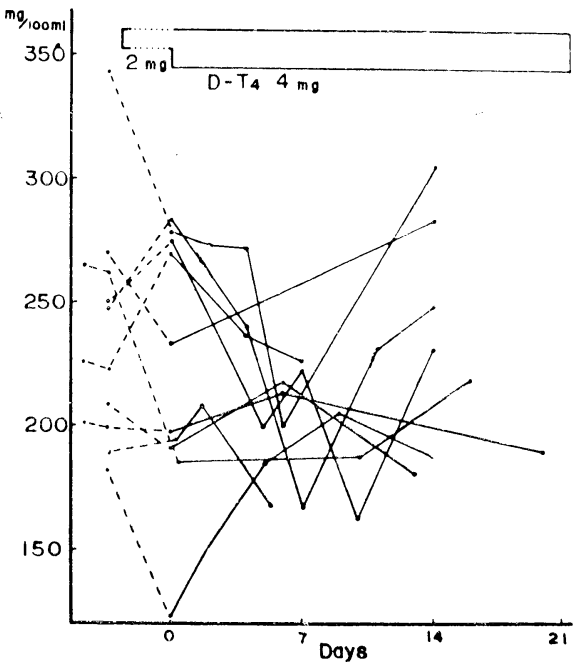

なかつたもの，或は $2 \mathrm{mg}$ の投与で低下していたものが $4 \mathrm{mg}$ でかえて escape のみられた症例もあつた。 $4 \mathrm{mg}$ で低下を示した 5 例の中 3 例にやはり 2 週前後で escape がみられた.

BMR 及び 血清 PBI 值についてはFig.17 I 及びIIにみられるように，2 mgの投与では一過性に+40\% を示した症例を除いては，BMR は軽度の上昇傾向を有するが目立つた変化はみられなかつた。 $4 \mathrm{mg}$ BMR の上昇傾向がみられ，一過性又は最終的に治療前より $20 \%$ 上上の上昇をきたした者が 3 例あつた。

Effects of $\mathrm{D}-\mathrm{T}_{4}$ on BMR \& PBI of Euthyroid Patients I

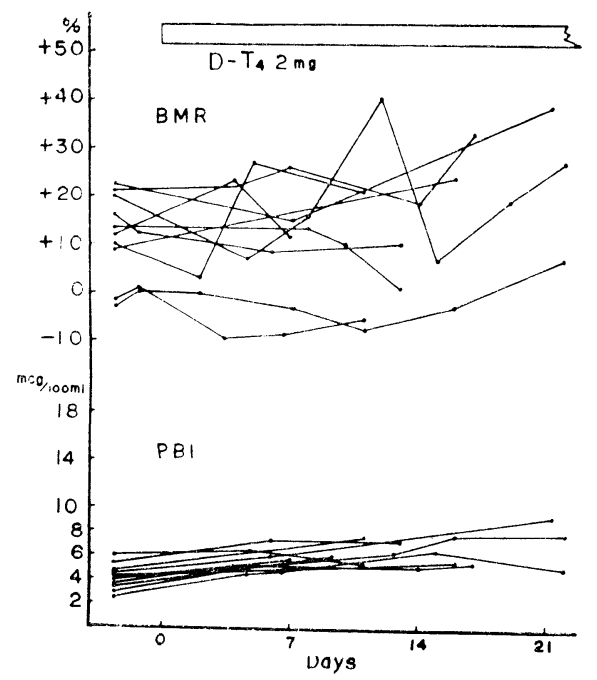

Fig. 17.

Effects of $\mathrm{D}^{-\mathrm{T}_{4}}$ on BMR \& PBI of Euthyroid Patients II

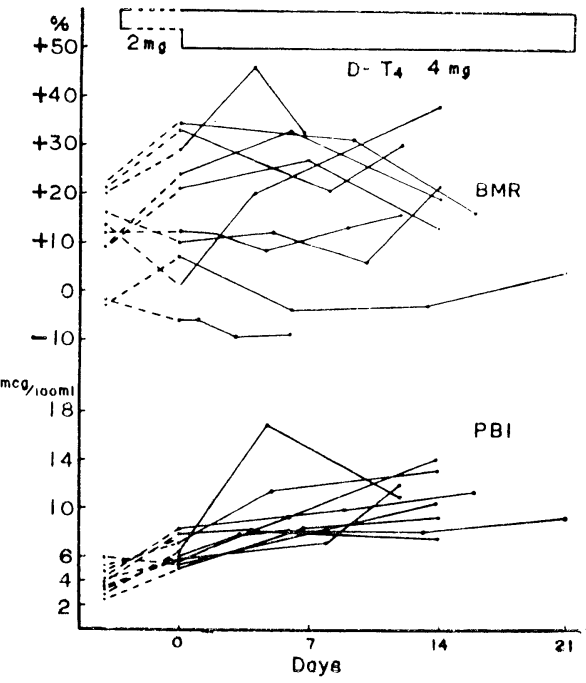

第38巻 第 9 号 
PBI は漸次上昇傾向を示したが $2 \mathrm{mg}$ では殆んど正常值を越えることなく，4 mgの投与では， 3 週後にも 尚正常範囲を示した 1 例を除いて，全例正常值以上となつたが， $15 \mathrm{mcg} / 100 \mathrm{ml}$ を越えなかつた.

Table 2. Metabolic \& Cholesterol Reducing Effects of D- $\mathrm{T}_{4}$ on Euthyroid Patients

\begin{tabular}{c|c|c|c|c|c|c|c}
\hline & $\begin{array}{l}\text { Control } \\
\text { Cholesterol } \\
\text { Patient (Sex) } \\
(\mathrm{mg} / 100 \mathrm{ml})\end{array}$ & $\begin{array}{c}\text { Max. Change } \\
\text { Dose } \\
(\mathrm{mg})\end{array}$ & $\begin{array}{l}\text { Chol. Level } \\
(\mathrm{mg} / 100 \mathrm{ml})\end{array}$ & $\begin{array}{l}\text { Ghol. } \\
\text { Change (\%) }\end{array}$ & $\begin{array}{l}\text { Fhol: } \\
\text { Change (\%) })\end{array}$ & $\begin{array}{c}\text { PBI } \\
(\mathrm{mcg} / 100 \mathrm{ml})\end{array}$ & $\begin{array}{c}\text { BMR } \\
(\%)\end{array}$ \\
\hline S. S. (M) & 209 & 2 & 178 & -14.6 & -13.2 & 10.6 & +20 \\
M. M. (M) & 343 & 4 & 200 & -41.8 & -10.8 & 7.6 & +29 \\
Y. I. (M) & 250 & 4 & 163 & -34.9 & -7.6 & 13.1 & +14 \\
T. H. (M) & 270 & 2 & 233 & -13.8 & +5.4 & 13.0 & +19 \\
M. T. (F) & 226 & 2 & 127 & -43.9 & 0 & 8.2 & +32 \\
T. S. (M) & 248 & 4 & 167 & -32.5 & 0 & 10.0 & +31 \\
M. I. (F) & 199 & 4 & 144 & -27.6 & -27.6 & 8.4 & +14 \\
N. N. (F) & 182 & 2 & 116 & -36.2 & +3.4 & 11.0 & +15 \\
K. H. (M) & 189 & 4 & 163 & -13.8 & -13.6 & 7.5 & -8 \\
I. M. (F) & 264 & 4 & 184 & -30.2 & -22.3 & 10.2 & +20 \\
\hline
\end{tabular}

これを表示すると Table 2 の如く，全経過で血清 cholesterolが最高の変化を示した時の平均低下率は28.9 \%であるのに比べて，投薬終了時では $20 \%$ 以上の低下を示しているものは 2 例に過ぎず，平均低下率は 8.6 \%で，てのととからも escape の存在がうかがわれた。 8 例で測定された甲状腺 $\mathrm{I}^{131}$ 摂取率は D-thyroxine 2 乃至 $4 \mathrm{mg}$ の投与で著明に抑制され，Table 3 に示されたように，1例を除いて10\%以下となつた.

Table 3. Effects of $\mathrm{D}-\mathrm{T}_{4}$ on Thyroidal $\mathrm{I}^{131}$ - Uptake of Euthyroid Patients

\begin{tabular}{c|c|c|c}
\hline Patient (Sex) & Premedication & Post-medication & Days \\
\hline S.S. (M) & $17.5 \%$ & $4.7 \%$ & 27 \\
M. S. (M) & 16.0 & 1.9 & 27 \\
Y. . (M) & 11.0 & 4.3 & 28 \\
T.H. (M) & 12.5 & 1.8 & 32 \\
M.T. (F) & 22.6 & 2.6 & 30 \\
T.S. (M) & 18.0 & 4.2 & 36 \\
M. I. (F) & 6.5 & 3.4 & 69 \\
N. N. (F) & 45.7 & 14.2 & 22 \\
\hline Average & 18.7 & 4.6 & \\
\hline
\end{tabular}

\section{Acetyl $\mathbf{T}_{3}$-formic acid の血清脂質低下作用}

5 例の甲状腺機能正常者に28乃至90日間, acetyl $\mathrm{T}_{3}$-formic acid を漸增法により 1 日 $25 \mathrm{mg}$ より55乃至 90 $\mathrm{mg}$ まで及び 5 例に初回より 1 日 $60 \mathrm{mg}$ を 3 ケ月以上にわたり投与した.

Fig.18の症例 Y. O. には acetyl $\mathrm{T}_{3}$-formic acid が漸增法により 1 日 $25 \mathrm{mg}$ より $70 \mathrm{mg}$ まで84日間投与さ れた。治療前の成績の平均值は, 血清cholesterol は $268.5 \mathrm{mg} / 100 \mathrm{ml}$, phospholipids $236 \mathrm{mg} / 100 \mathrm{ml}$, lipoprotein 比 $3.95, \mathrm{BMR}-11.0 \%, \mathrm{PBI} 5.8 \mathrm{mcg} / 100 \mathrm{ml}$ 及び甲状腺 $\mathrm{I}^{131}$ 摂取率は $18.0 \%$ あつた。 
Fig. 18

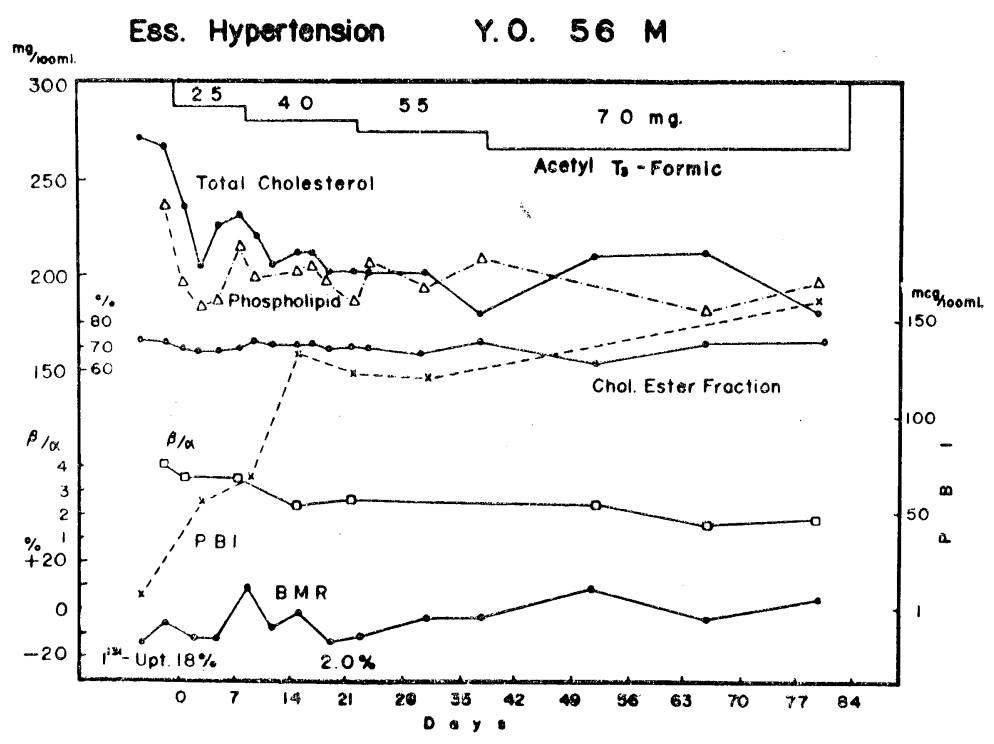

最初 1 日25mgの投与で血清脂質は急速に低下を示し, 投与 4 日目に cholesterol $204 \mathrm{mg} / 100 \mathrm{ml}$, phospholipid は $183 \mathrm{mg} / 100 \mathrm{ml}$ と著明な低下をみたが，兩者はこの投与量の持続で上界傾向がみられた。しかし增 量することにより更に低下傾向を示し，cholesterol はほぼ $200 \mathrm{mg} / 100 \mathrm{ml}$ 前後の值を維持できた．最高の低 下は $55 \mathrm{mg}$ 投与時 $179 \mathrm{mg} / 100 \mathrm{ml}$ と $33.3 \%$ の低下を示した. 最後の 4 週間の值を平均した最終観察時では 27.5 \%の低下であつた. Phospholipids は最終的には低下がそれ程著明ではなかつたが， G/P比は1.14より1.00 と低下がみられた. Lipoprotein 比も漸次低下をきたし，投与終了時1.97と正常值を示した。

BMR に対しては投与初期にわずかな変動がみられ，全体的に軽度上昇傾向が認められたが，最終観察時 +3.5\%であつた，血清 PBI は投与量の増加に従つて著明な上昇をきたし，投与終了時 $160 \mathrm{mcg} / 100 \mathrm{ml} \mathrm{に}$ まで上昇し，甲状腺 $\mathrm{I}^{131}$ 摂取率は投与 21 日で $2.0 \%$ と著明に抑制された。 EGG では投与前後で特に变化はみ られなかつた。

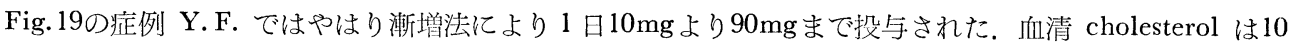
$\mathrm{mg}$ の投与で $249.0 \mathrm{mg} / 100 \mathrm{ml}$ より $226 \mathrm{mg} / 100 \mathrm{ml}$ 亿, phospholipids は $236 \mathrm{mg} / 100 \mathrm{ml}$ よ $200 \mathrm{mg} / 100 \mathrm{ml}$ に低下 をきたしたが，その後 $20 \mathrm{mg}$ に増量しても上昇傾向がみられ，60 mg 投与で更に治療前值以上の值を示し， $90 \mathrm{mg}$ の投与でも低下をみなかつた，Lipoprotein 比は治療前も正常範团にあり，投与後も特に变化はみら れなかつた，BMR はわずかに上昇傾向が認められたが，+10\%を越えず，ただ $90 \mathrm{mg}$ の投与で一過性に十 $18 \%$ 示した. PBI は投与終了洔 $131 \mathrm{mcg} / 100 \mathrm{ml}$ と著明に上昇した. ${ }^{131}$ 摂取率は21日で $0 \%$ に抑制された。

Fig. 20 の症例 T.K. は大動脈分不全及び高度の左室肥大を有する動脈硬化性心疾患の患者である，Acetyl $\mathrm{T}_{3}$-formic acid は25mgより60mg まで漸㦈的に77日間投与された。血清 cholesterol は1 日25mgの投 与により $240 \mathrm{mg} / 100 \mathrm{ml} り 198 \mathrm{mg} / 100 \mathrm{ml}$ 急速な低下をきたした. $35 \mathrm{mg}$ 投与中も殆んど $200 \mathrm{mg} / 100 \mathrm{ml}$ 前 後の值を維持していたが，35日以後に至り，43mgの投与にかかわらず，escape をきたし，治療前の值以上 となつた. $60 \mathrm{mg}$ 亿増量した所，再度低下をきたし，投与終了時 $201 \mathrm{mg} / 100 \mathrm{ml}$ でつた. Phospholipids も cholesterol に一致した経過を示した. 比較的 BMR 上昇作用の少ない acetyl $\mathrm{T}_{3}$-formic acid でも, 高度 の心疾患を有する本症例では，やはり多少 calorigenic に働き，BMR は25mg の投与で一過性に+23.8\% と上昇し，自覚的にも軽度の心悸充進及び発汗を訴えた。しかし BMR は投与持続により間もなく治療前 值にもどり，自覚的症状も消失した．更に $60 \mathrm{mg}$ を投与した所，再度心悸充進，発汗を訴え，BMRも+28.5 
Fig. 19.

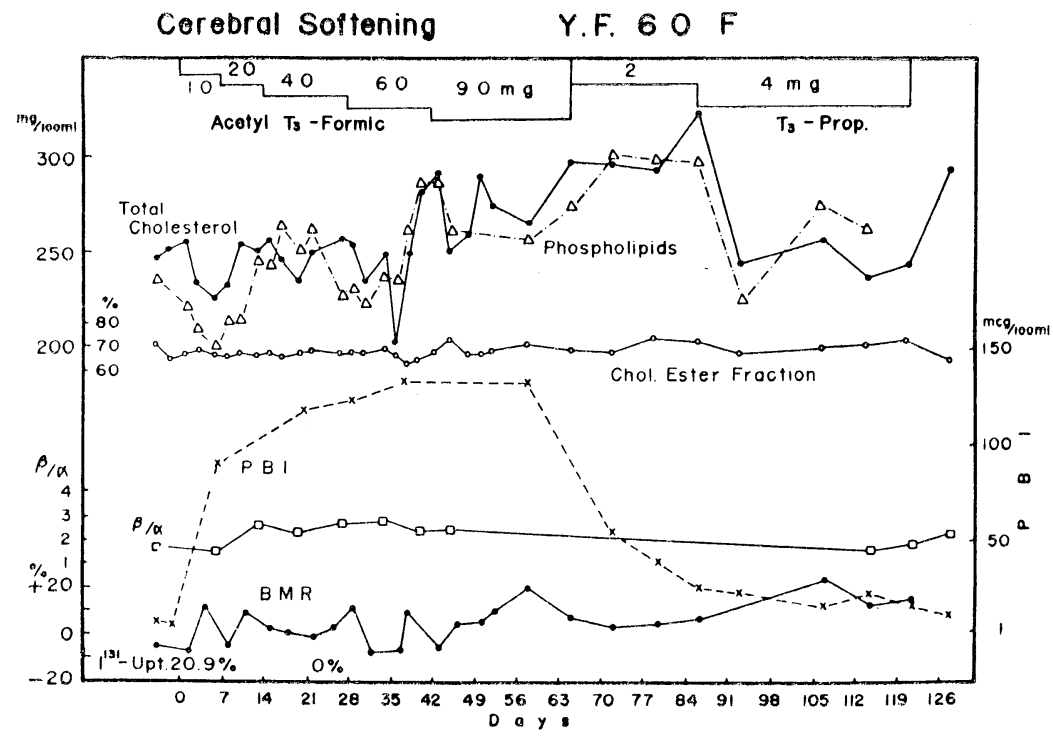

$\%$ と増加し， 2 週後には +2

Fig. 20.

\%にもどつたが，投薬は万一 の伦険を考慮して中止された。 PBI はやはり $202 \mathrm{mcg} / 100 \mathrm{ml}$ と異常な高值を示した. ECG では投与前後でみるべき変化 はみられなかつた。

以上漸増法により acetyl $\mathrm{T}_{3}$-formic acid を甲状腺機能 正常者の血清脂質を低下させ る目的で使用されたが，血清 脂質は少量の投与で既に急速 且つ著明な低下をきたすが， その持続を保ち得ず，投与量 を增加しても escape をきた しやすいように思われた。一 方 Strisower 等 ${ }^{7778)}$ は，ての

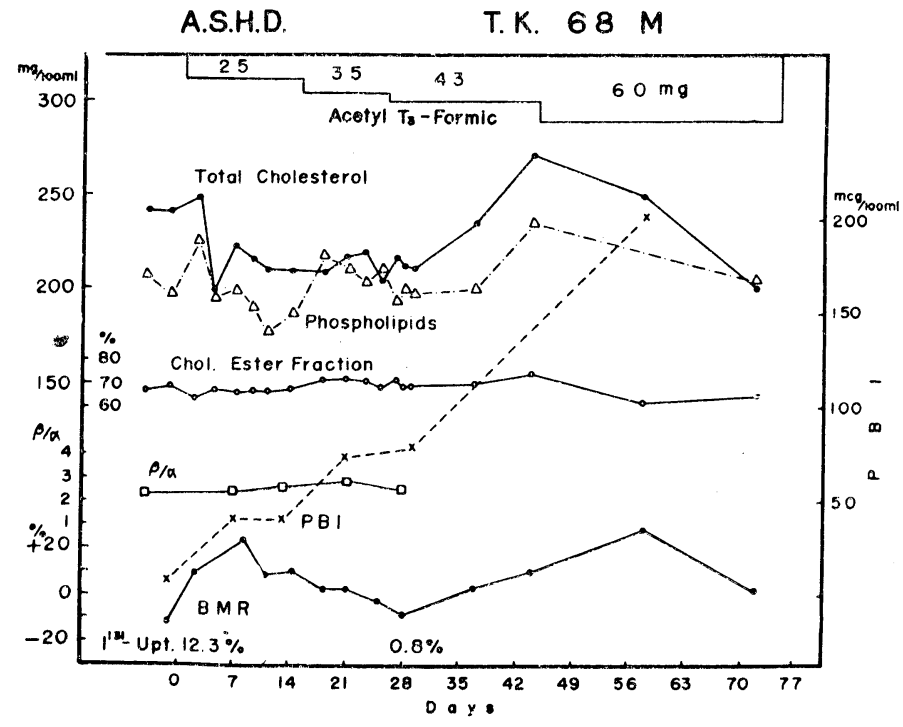
escape は外因性の thyroid hormone の投与で，下垂体よりの thyrotropin の分泌方低下し，徐々に内四性の thyroid hormone の分 泌減少が起る。それで外因性 thyroid hormone の投与量が少ない場合は，循興血中の thyroid hormone 量が治療前に及ばず escape をみると仮定し，外因性の hormone を充分量に增すならば，田状腺の hormo一 ne 分泌が完全に杜絶した場合でさえも，循環血中の thyroid hormone 量は治療前の1 日生産量を上廻 り， escape をみないであろうと考えた。 それで195mgの乾燥甲状腺で cacape がみられたが，1日260mg 及び325mg以上では30週にわたり escape をみなかつたことを報告している。

この見解にもとづいて，1 日60 mg と比較的大量の acetyl $\mathrm{T}_{3}$-formic acid を初回より使用した. 
Fig.21亿示した症例 F.K. では初回より 1 日60mgの acetyl $\mathrm{T}_{3}$-formic acid が投与され，160日以上に わたり観察された。治療前の検查成績の平均は, 血清 cholesterol $251.5 \mathrm{mg} / 100 \mathrm{ml}$, phospholipids $223 \mathrm{mg} / 100$ $\mathrm{ml}, \mathrm{C} / \mathrm{P}$ 比 1.15 , lipoprotein 比 $4.84, \mathrm{BMR}-8.3 \%, \mathrm{PBI} 4.8 \mathrm{mcg} / 100 \mathrm{ml}$ であつた.

Fig. 21.

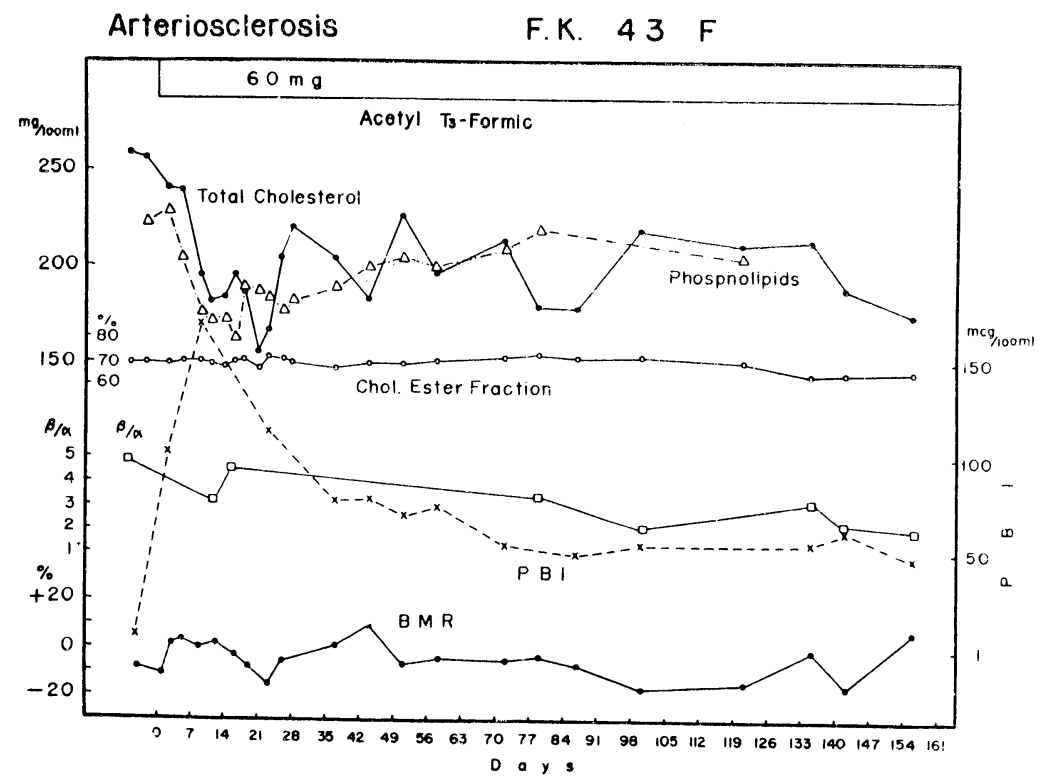

Acetyl $\mathrm{T}_{3}$-formic acid 1 日60 mg が投与されると血清脂質は速が著明な低下をきたし， phospholipids は16日目に $163 \mathrm{mg} / 100 \mathrm{ml} ，$ cholesterol は22日目に $155 \mathrm{mg} / 100 \mathrm{ml}$ と最低を示し，それぞれ $27.9 \%$ 及び $38.4 \%$ の低下をみた，その後はいくらか上昇傾向がみられたが，160日の投与期間を通じて，cholesterol は上く200 $\mathrm{mg} / 100 \mathrm{ml}$ 前後の值を維持し, 最終観察では平均 $21.9 \%$ の低下がみられた. 又 $\mathrm{C} / \mathrm{P}$ 比も1.03亿, lipoprotein 比も2.05に低下した. BMR は一過性に軽度の上昇が認められたが，+10\%を越えるととはなかつた。 PBI は投与後急速に上昇し，9 日目に $169 \mathrm{mcg} / 100 \mathrm{ml}$ に達したが，その後同一量投与にもかかわらず漸次低下を きたした。しかし最終観察時尚 $47.3 \mathrm{mcg} / 100 \mathrm{ml}$ であつた。投与前後で ECG 亿変化はみられなかつた。

症例 R. S. (Fig.22) でもやはり初回より 1 日 $60 \mathrm{mg} の$ acetyl $\mathrm{T}_{3}$-formic acid が，126日間にわたり 投与された。治療前の検査成績では血清 cholesterol は平均 $282.5 \mathrm{mg} / 100 \mathrm{ml}$, phospholipids $244 \mathrm{mg} / 100 \mathrm{ml}$, $\mathrm{C} / \mathrm{P}$ 比 1.16, lipoprotein 比 $3.76, \mathrm{BMR}-9.8 \%, \mathrm{PBI}$ は $5.2 \mathrm{mcg} / 100 \mathrm{ml}$ であつた.

血清脂質の最大の低下は，やはり投与早期にみられ，2 週前後で cholesterol は172mg/100mlと39.1\%の 減少, phospholipids は $150 \mathrm{mg} / 100 \mathrm{ml}$ と38.5\%の低下をきたした。最終観察時の平均では, cholesterol は 25.1\%の低下をみており，phospholipids は7.0\%の減少にすぎないが， C/P 比は0.96と低下し， lipoprotein 比も 2.20 となつた. BMR は前例と同様, 投与初期に軽度の上昇がみられたが，その後治療前値にもぞ り, 最終観察時では平均 $+1.6 \%$ であつた，PBI は最高 $152 \mathrm{mcg} / 100 \mathrm{ml}$ にまで上昇したが，最終観察では 116 $\mathrm{mcg} / 100 \mathrm{ml}$ であつた，投与前後の ECG では変化がみられず，Scheie IV 度の眼底所見も投与により改善 はみられなかつた。

10例の甲状腺機能正常者に acetyl $\mathrm{T}_{3}$-formic acid を投与した結果を表示する.

Table 4 亿於て，A表は漸増法で微量より投与され，B表では最初より1 日60 $\mathrm{mg}$ が投与された。

漸増法で投与された 5 例では，血清 cholesterol は最高の低下をきたした時で平均18.9\%であるが，最終 観察封の平均では $+1.6 \%$ と殆んど治療前の值にまでもどり，症例 Y. O. のみが最終的にも $27.5 \%$ の低下 
Fig. 22.

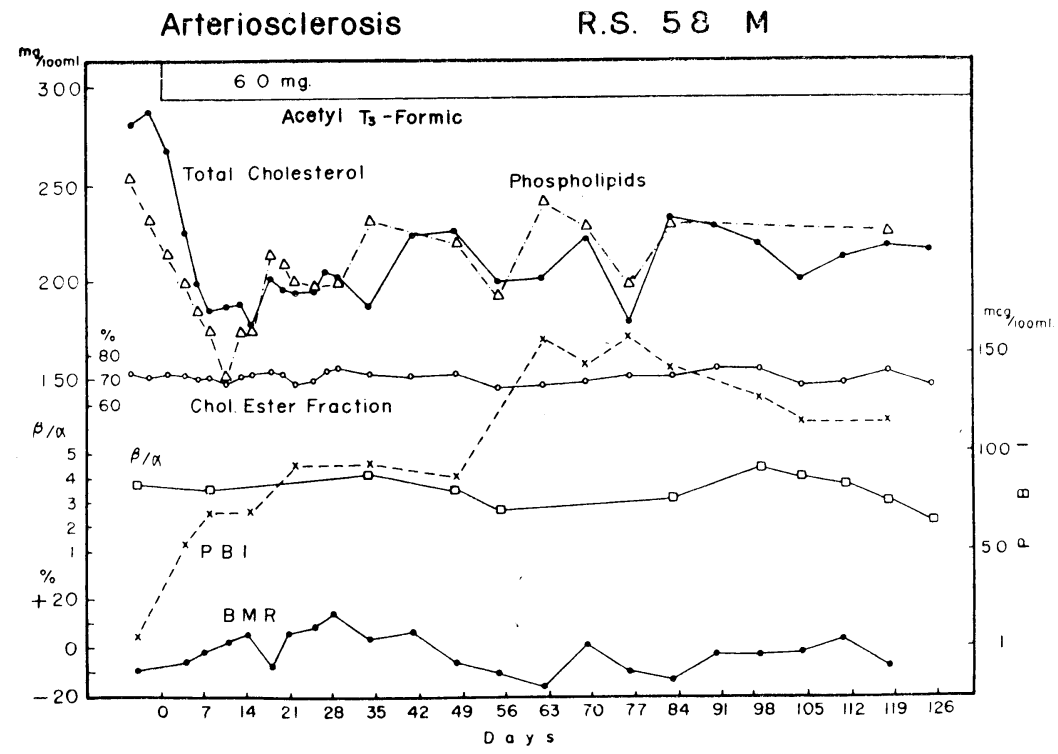

Table 4. Metabolic \& Cholesterol Reducing Effects of Acetyl $\mathrm{T}_{3}$-Formic Acid on Euthyroid Patients

\begin{tabular}{|c|c|c|c|c|c|c|c|c|c|}
\hline \multirow{2}{*}{$\begin{array}{c}\text { Patient } \\
(\operatorname{Sex})_{1}\end{array}$} & \multirow{2}{*}{$\begin{array}{l}\text { Control } \\
\text { Cholesterol } \\
\text { Level } \\
(\mathrm{mg} / 100 \mathrm{ml})\end{array}$} & \multicolumn{3}{|c|}{ Max. Change } & \multicolumn{3}{|c|}{ Final Observation } & \multirow{2}{*}{$\left(\begin{array}{c}\text { Dose } \\
\left(\frac{\mathrm{mg}}{\mathrm{day}}\right)\end{array}\right.$} & \multirow{2}{*}{$\begin{array}{l}\text { Dura- } \\
\text { tion } \\
\text { (days) }\end{array}$} \\
\hline & & $\begin{array}{l}\text { Dose } \\
(\mathrm{mg})\end{array}$ & $\begin{array}{l}\text { Chol. Level } \\
(\mathrm{mg} / 100 \mathrm{ml})\end{array}$ & $\begin{array}{l}\text { Chol. } \\
\text { Change } \\
(\%)\end{array}$ & \begin{tabular}{|c|} 
Chol. \\
Change \\
$(\%)$
\end{tabular} & $\begin{array}{c}\text { PBI } \\
(\mathrm{mcg} / 100 \mathrm{ml})\end{array}$ & $\underset{(\%)}{\mathrm{BMR}}$ & & \\
\hline A) & Increased & \multicolumn{8}{|l|}{ Doses } \\
\hline T.M. (F) & 235.0 & 25 & 216 & -8.1 & -2.2 & 71 & +5.8 & $25-55$ & .28 \\
\hline T.H. (M) & 203.0 & 25 & 170 & -16.3 & +5.4 & 78 & -7.3 & $25-60$ & . 32 \\
\hline Y.F. (F) & 249.0 & 60 & 201 & -19.3 & +33.0 & 131 & +5.9 & $10-90$ & . 66 \\
\hline T.K. (M) & 240.0 & 25 & 198 & -17.5 & -0.7 & 202 & +10.8 & $25-60$ & .72 \\
\hline $\mathrm{Y} \cdot \mathrm{O} \cdot(\mathrm{M})$ & 268.5 & 55 & 179 & -33.3 & -27.5 & 160 & -3.5 & $25-70$ & .90 \\
\hline \multicolumn{10}{|c|}{-18.9} \\
\hline \multicolumn{10}{|c|}{ Relatively Large Doses } \\
\hline $\mathrm{F} \cdot \mathrm{K} \cdot(\mathrm{F})$ & 251.5 & 60 & 150 & -38.4 & -21.9 & 47 & -6.0 & 60 & .156 \\
\hline $\mathrm{R} \cdot \mathrm{S} \cdot(\mathrm{M})$ & 282.5 & 60 & 172 & -39.1 & -25.1 & 116 & +1.6 & 60 & .125 \\
\hline $\mathrm{J} \cdot \mathrm{T} \cdot(\mathrm{M})$ & 305.0 & 60 & 188 & -38.4 & -22.3 & 118 & -6.7 & 60 & .91 \\
\hline $\mathrm{K} \cdot \mathrm{I} \cdot(\mathrm{M})$ & 275.0 & 60 & 175 & -36.5 & -23.8 & 66 & & 60 & . 99 \\
\hline M.K. (F) & 273.5 & 100 & 188 & -32.5 & -13.1 & 252 & +10.2 & $60-100$ & .105 \\
\hline \multicolumn{10}{|c|}{$-37.0-21.2$} \\
\hline
\end{tabular}

を維持しているにすぎなかつた.

初回より 1 日 $60 \mathrm{mg}$ を投与されたB表では, cholesterol の最大の低下は平均 $37 \%$ と著明であり, 最終観察 時でも $21.2 \%$ 低下を示している，乙のことからも初回より比較的大量を投与した方が escape を起しにく 
いと思われる。

A表，B表共に最終的に PBI の上昇は著明であつた。 BMR は全例正常值を越えなかつた。Table 5 は 7 例で測定された甲状腺 $\mathrm{I}^{131}$ 掑取率の抑制効果を示したものである. Acetyl $\mathrm{T}_{3}$-formic acid 投与 14 乃至 28 日で $\mathrm{I}^{113}$ 摂取率は平均 $1.12 \%$ と著明な抑制がみられた。

Table 5. Effects of Acetyl $\mathrm{T}_{3}$-Formic Acid on Thyroidal $\mathrm{I}^{131}$ - Uptake of Euthyroid Patients

\begin{tabular}{c|c|c|c}
\hline Patient (Sex) & Premedication & Post-medication & Days \\
\hline T.M. (F) & $34.5 \%$ & $1.65 \%$ & 18 \\
T.H. (M) & 13.8 & 2.08 & 25 \\
Y.F. (F) & 20.9 & 0 & 19 \\
T.K. (M) & 12.3 & 0.80 & 28 \\
Y.O. (M) & 18.0 & 2.02 & 21 \\
M.K. (F) & 10.9 & 1.04 & 13 \\
S.N. (F) & 21.5 & 0.20 & 14 \\
\hline Average & 19.6 & 1.12 & \\
\hline
\end{tabular}

\section{V. 考按並びに総括}

Thyroid hormone の充分量が甲状腺機能正常者に投与された場合でも，粘液水腫患者にみられたと同様 に，やはり血清脂質の低下がみられることは広く知られている。

乾燥甲状腺 ${ }^{778)}$, L-thyroxine $\left.{ }^{8) 10}\right)^{80}$ ), L-triiodothyronine ${ }^{10) 67)}$ の投与で, 甲状腺機能正常者でも, total lipids, phospholipids, cholesterol 及び $\beta$-lipoprotein 又は Sf0-12, Sf12-20, lipoprotein の低下がみられている. しかしてれらの効果も比較的小量では長期の投与で escape をきたしやすく，又その低下を維持できる程度 に増量すれば BMR の上昇，心搏数の増加，体重減少等の代謝充進の症状をきたし，又冠不全の患者では， 狭心症の頻発がみられるといわれ，脂質降下剤としては不適である。

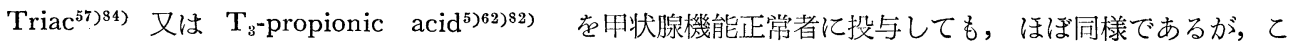
のものでは BMR の上昇の程度は，L-thyroxine や L-triiodothyronine の場合よりも軽度のようである。

\section{1. 血清脂質低下作用}

1) D-thyroxine

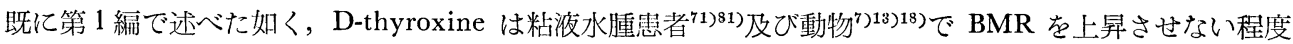
の投与量で，血清又は肝 cholesterol を低下させうるてとが知られている. 更に最近，甲状腺機能正常者で， BMR 又は ECG に変化を与えるととなく，長期にわたり血清 cholesterol を低下させえたという報告は多

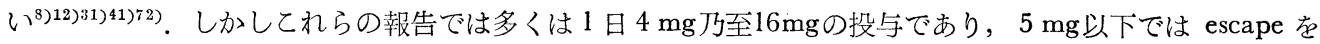
きたしやすい゙1) といわれている。本編に於ける D-thyroxine 投与例では，4 mg ですでに BMR は上昇傾 向を示し，又 $2 \mathrm{mg}$ 及び $4 \mathrm{mg}$ で escape の傾向が認められた. $4 \mathrm{mg}$ 投与でみられた BMR の上昇は上記報 告者の結果と異なるが，乙れは恐らく日本人と外国人との体格的相異に埽せられるものと考えられる.

2) Acetyl $T_{3}$-formic acid

Thyroxine 及び triiodothyronine の formic acid analogues は動物で酸素消費量又は心藏に対する作用 よりも，血中及び肝の cholesterol に大きな効果を有するといわれて11)18)20)66)， $\mathrm{T}_{4}$-formic acid は粘液水腫 患者に投与された場命，BMR 在上昇させない投与量で向㠸 cholesterol を低下させうることが知られてい

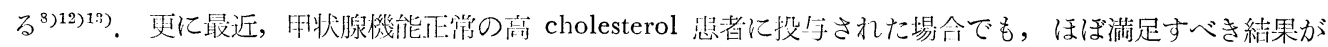
報告されている ${ }^{8) 12) 16)}$. しかし未だ $\mathrm{T}_{3}$-formic acid group を甲状腺機能正常者に使用した報告はみうけら 
れない.

Table4でみられた如く, 漸増的に acetyl $\mathrm{T}_{3}$-tormic acid を投与した場合, 比較的少量の投与で cholesterol の低下がみられたが， escape をきたしやすく，最終観察では治療前の值に戻る傾向がみられた，先 に述べたように Strisower 等の見解にもとづき，初回より $60 \mathrm{mg}$ と比較的大量の投与を試みた所，投与初期 に血中 cholesterol の最大の低下がみられたが，3ケ月以上の観察でも，よくその低下が維持された。そし て血中 cholesterol は正常值を越えて低下することはなく, L-thyroxine で指摘された ${ }^{79}$ 如く，てのもので も治療前の值の高い程低下は著明なようである. 更に cholesterol の低下は, L-thyroxine, L-triiodothyronine 及び乾燥甲状腺投与でみられたと同様, phospholipids, $\beta$-lipoprotein の低下を伴い, C/P 比も低下の 傾向がみられた，従つて血中脂質全体に低下傾向を示すもののようである. よつて現在の段階では血中脂質 降下剂として最も有用な thyroxine analogue と考えられる。

\section{2. 心臟に対する作用}

粘液水腫患者又は狭心症の既往のある患者に thyroid hormone を投与すると狭心症発作の增悪する場合 のあるてとが知られている。

Oliver and Boyd $\left.{ }^{57}\right)$ 及び Ibbertson, Fraser and Alldis ${ }^{40}$ は微量の triac を冠不全の患者汇投与し BMR の 上昇なしに血中 cholesterol の低下をみたが，しかし中には，BMR の変化なしに狭心症をきたす症例もあ り, triac では心筋は骨骼筋, 筒及び肝等より酸素消費量が增大する ${ }^{10)}$ といわれている. 又他の a nalogues についても BMR の上昇なしに狭心症をきたす可能性があると考元られている ${ }^{12}$.

動物での実験でも tetrac 及び $\mathrm{T}_{4}$-propionic acid は L-thyroxine より血中及び心筋に多く集まり ${ }^{37)}$, 又 D-thyroxine は心筋への集まりは少なく，心筋の酸素消費量の増加は L-thyroxine の方が多い ${ }^{83}$ とい われる. そして rat で D-thyroxine, D-triiodothyronine, $\mathrm{T}_{4}$-formic acid, $\mathrm{T}_{3}$-formic acid 等は，心蔵に 対する作用が他のものに比べて少ない1118)とされている．人の粘液水腫患者でも L-thyroxine，乾燥甲状腺 で治療中は狭心症が頻発していた症例で，D-thyroxine 投与により甲状腺機能正常となり，狭心症発作がみ られなくなつたという報告 ${ }^{22}$ がある。臨床的にも D-thyroxine は他の analogues に比して狭心症をきたす 作用は弱く ${ }^{12)}$ ，動脈硬化性心疾患の患者でも，1日4 mg以下なら安全といわれている ${ }^{31172)}$.

Formic acid group については, 最近 Best and Dancan ${ }^{8}$ は心疾患の患者に $\mathrm{T}_{4}$-formic acid を 1 日200 $\mathrm{mg}$, 又は dimethyl $\mathrm{T}_{2}$-formic acid $100 \mathrm{mg}$ を投与し, 狭心症又は心不全の悪化をみなかつた。 しかし Boyd and Oliver ${ }^{12)}$ はやはり㹨心症の既往のある者に， $\mathrm{T}_{4}$-formic acid を投与し，1 日200mgの投与では増 悪はみられなかつたが，200〜300 mgを投与された6 例の中 2 例に BMR の上昇と㹨心症の悪化をみている.

Acetyl $\mathrm{T}_{3}$-formic acid 投与の症例 T. K. については狭心症の発来はみられなかつたが，一過性の BMR 上昇と心愁訴があり, やはり心不全の症例では $60 \mathrm{mg}$ 以下の投与が安全と思われる.

しかし最近では更に積極的に，狭心症発作の頻発する症例に対して $\mathrm{I}^{131}$ とり人工的に甲状腺機能低下を きたさしめるとよいといわれ(916)，後療法として，てのような BMR 上昇作用の弱い analogue を投与す るととが，更に好結果をもたらすであろうと考えられる。

\section{3. $\mathrm{PBI}$ の変化}

Thyroxine analogues 投与による PBI の変化は, 必ずしも反応の程度を示すものではなく, triac 投与 により BMR がかなり上昇しているにかかわらず，PBI の上昇はでくわずかな症例がある一方，他の症例 で BMR は㱠んど不変であるのに，PBI はかえつて上昇を示すてとがあり，PBI と BMR は必ずしも平 行しないといわれている ${ }^{50)}$. このことは analogue の種類についても知られており, triac は tetrac より も，及び D-thyroxine は L-thyroxine よりも PBI を上昇せしめる作用は弱い44).

甲状腺機能正常者に D-thyroxine $4 \mathrm{mg}$ を投与した場合 Table 2 そみられるように，PBI の上昇は軽度で あつた。 Acetyl $\mathrm{T}_{\mathrm{g}}$-formic acid を投与した場合はその増量に従つて PBI は著明な上昇をきたした。最初 より $60 \mathrm{mg}$ を投与された症例では，PBI は急速又は比較的速かに著明な上昇をきたし，ほぼ $150 \mathrm{mcg} / 100 \mathrm{~m}$ 以 上の值を示したが，その後漸次下降し，投与 3 ケ月以上で同一量の持続にかかわらず 50 乃至 $100 \mathrm{mcg} / 100 \mathrm{ml}$ 
程度の值を維持した. この原因についての説明も現在の所不明である. 正常者の場合 cholesterol 值の escape 現像と同様な意味を有するものかも知れない.

\section{4. 甲状腺 $\mathbf{I}^{131}$ 摂取率抑制効果}

D-thyroxine 及び acetyl $\mathrm{T}_{3}$-formic acid 投与後の甲状腺 $\mathrm{I}^{131}$ 湶取率は全例著明に抑制された。 Analo-

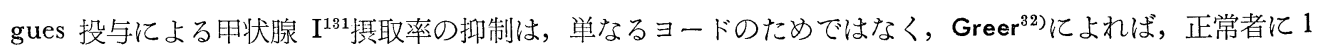
日 $65 \mathrm{mg}$ の微量の乾燥甲状腺を 3 週間投与すると $\mathrm{I}^{131}$ 摂取率の著明な抑制がみられるが，それに含まれると 同量のヨードを投与しても，その抑制は殆んどみられないか，でくわずかなととが知られている，又，同じ

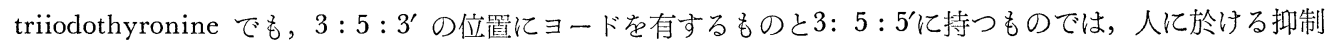
効果は, 後者では前者の1/100より小さいといわれている70). 従つて大量の thyroxine analogues による甲 状腺機能の抑制は，その一部はヨードによる直接作用も否定できないが，下垂体を介して抑制されるてとが 大きいものと考光られる ${ }^{(1)}$.

D-thyroxine 及び $\mathrm{T}_{3}$-formic acid の rat に於ける $\mathrm{I}^{131}$ 揕取率抑制効果は，それぞれ L-thyroxine の50 \%及び15\%であるといゔ

\section{VI. 結 論}

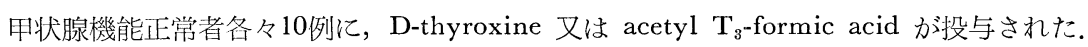

1) D-thyroxine 4mg の投与で, 甲状腺機能正常者でも軽度の BMR 上昇傾向がみられた。血清 cholesterol 飞対しては $4 \mathrm{mg}$ 以下の投与で escape をきたしやすいと思われた。

2) D-thyroxine 4mg の投与では PBI の上昇は比較的軽度であつたが，甲状腺 $\mathrm{I}^{131}$ 摃取率は著明に抑 制された。

3 ) Acetyl $\mathrm{T}_{3}$-formic acid を甲状腺機能正常者に投与した場合，1 日25 60mgの投与で BMR の上昇 はでくわずかであり，血清脂質全体に著明な低下をきたすが，漸増法で投与した場合は escape が起りやす いように思われる。

4) Acetyl $\mathrm{T}_{3}$-formic acid を最初より 1 日 $60 \mathrm{mg}$ 程度の比較的大量を投与した場合, BMR の上昇はで くわずかで, 血清 cholesterol は $200 \mathrm{mg} / 100 \mathrm{ml}$ 前後の值を 3 ケ月以上にわたり持続しえた. 従つて血中脂 質降下鼡として有用と思われた。

5 ) Acetyl $\mathrm{T}_{3}$-formic acid で，PBI は投与量の增加に従つて著明に上昇した。 しかし同一量を長期にわ たり継続した場合低下傾向を示したが，乙の理由は不明である。闸状腺 $\mathbf{I}^{131}$ 摆取率は著明に抑制された。

6 ） 1 例の高度の心不全患者に 1 日 $60 \mathrm{mg} の$ acetyl $\mathrm{T}_{3}$-formic acid が投与され，BMR の軽度上昇と心 愁訴が認められた。实患を有する症例では，60 $\mathrm{mg}$ 以下の投与が望ましいと思われる。

終るに当り，終始御䅰篤なる御指導及び御校閲をいただいた恩師西川光夫教授並びに熊岡爽一講師に深く 感謝いたします。御協力总いただいた研究室の諸先生に謝意を表します。

\section{文献}

1) ADLERSBERG, D. : Am. J. Med., 23 : 769 789, (1957).

2) AHRENS, E.H., JR. and H. G. KUNKEI : J. Exp. Med., $90: 409 \sim 424$, (1949). $\quad$ 3) ASPER, S.P. JR., H.A. SELENKOW and G.A. PLAMONDON : Bull. Johnes Hopkins Hosp., $93: 164 \sim 198$, (1953). 4) BARKER, S.B., M. J. HUMPHREY and M.H. SOLEY : J. Clin. Inivest., 30:55 62, (1951). 5) BAUER, H.G., T.H. McGAVACK and L. SWELL : J. Clin. Endocrinol. and Metabol., $19: 490 \sim 493$, (1959). 6) BENUA, R.S., R.D. LEEPER, S. KUMAOKA and R.W. RAWSON : Ann. N.Y. Acad. Sci., 86 : 563 581, (1960). $\quad$ 7) BEST, M.M. and G.H. DUNGAN : Am. J. Physiol., 199 : 1000 1002, (1960). $\quad$ 8) BEST, M.M. and C.H. DUNGAN : Girculation. 24 : 58 67, (1961). 
BLUMGART, H.L., A.S. FLEEDBERG and G.S. KURLAND : J.A.M.A., $157: 1 \sim 4$, (1955).

10) BOYD, G.S. and M.F. OLIVER : Bull. Schweiz. Akad. Med. Wiss., 13 : 384 395, (1957).

11) BOYD, G.S. and M.F. OLIVER : J. Endocrinology, $21: 25 \sim 32$, (1960). 12) BOYD, G.S. and M.F. OLIVER : J. Endocrinology, $21: 33 \sim 43$, (1960). 13) BOYD, G.S. and M.F. OLIVER : Brit. Med. Bull., $16: 138 \sim 142$, (1960). 14) BROWN, E.F. and F.A. MORGAN : J. Nutrition, $35: 439 \sim 452,(1948)$.

15) BRUGER, M. and J.A. ROSENKRANZ : J. Clin. Endocrinol. and Metabol., $2: 176 \sim 180$, (1942). 16) CORDAY, E., D.W. IRVING and H. JAFFE : Circulation, $22: 677,(1960)$.

17) GROSLEY, A.P., JR., F. ALEXANDER and W.H. STRICKLAND : Symposium on Derivatives and Isomers of Thyroid Hormones, (1960), 55 60, Philadelphia.

18) GUTHBertson, W.F.J., P.V. ELCOATE, D.M. IRELAND, O.C.B. MILLS and P. SHEARLEY : J. Endocrinology, $21: 45 \sim 68,(1960)$.

Ann. Int. Med., $11: 354 \sim 369$, (1937).

19) DAVIS, D., B. STERN and G. LESNICK :

20) DUNCAN, C.H. and M.M. BEST : Endocrinology $63: 169 \sim 176$, (1958). 21) DUNCAN, C.H. and M.M. BEST : Circulation, $22: 660$, (1960).

22) DYSON, A. and M.W.W. WOOD : Lancet, $2: 757 \sim 759$, (1956). $\quad 23)$ FIELD, H., JR., L. SWELL, P.E. SGHOOLS, JR.,and C.R. TREADWELL : Circulation, $22: 547 \sim 558$, (1960).

24) FISKE, C.F. and Y. SUBBAROW : J. Biol. Chem., $66: 375 \sim 400,(1925) . \quad 25)$ FOLIN, O. : J. Biol. Chem., 101 : 111 125, (1933). 26) FORD, R.V., J.C. OWENS, G.W. GURD, JR., J. H. MOYER and C.L. SPURR : J. Endocrinol. and Meta., $21: 548 \sim 554,(1961) .27$ ) FRAWLEY, T. E., J.C. MCGLLINTOCK, R.T. BEEBE and G.L. MARTHY : J.A.M.A., $160: 646 \sim 652$, (1956). 28) GILDEA, E.F., E.B. MAN and J.P. PETERS : J. Clin. Invest., $18: 739 \sim 755$, (1939). 29) GOULD, R.G. and R.P. COOK : Chap. 7 in : Cholesterol, edited by R.P. Cook. New York : Acad. Press, (1958). 30) GREEN, R. and H.E.A. FARRAN : Brit. Med. J., II : 1057 1060, (1958). 31) GREEN, R., J.F. PEARCE and D.F. RIDEOUT : Brit. Med. J., 1 : 1572 1575, (1961).

32) GREER, M.A : New Engl and J. Med., $\left.244: 385 \sim 390 .^{\circ}(1951) . \quad 33\right)$ GROSS, J. : Science- 111 : 105 108, (1950). 34) GROSS, J. and R. PITT-RIVERS : Lancet, $1:$ 439 441, (1952). 35) HARRINGTON, G.R. and R. PITT-RIVERS : Biochem. J., $50: 438 \sim 439$, (1952). HART, F.D. and N.F. MAGLAGAN : Brit. Med., J., I : 512 518, (1950).

37) HATFIELD, W.B., F.F. DAVIDOFF, J.E. ROSS and D.F. TAPLEY : Endocrinology, 66; 676 693, (1960).

38) HILL, S.R., JR., S.B. BARKER, J.H. McNEIL, J.O. TINGLEY and L.L. HIBBETT : J. Clin. Invest, 39 : 523 533, (1960). 39) HURXTHAL, L.M. : Arch. Int. Med., 53 : 762 781, (1934). 40) IBBERTSON, K., R. FRASER and D. ALLDIS : Brit. Med. J., II : 52〜58, (1959). JONES, R.J. : Symposium on Sodium D-Thyroxine, (1959), 71 74, Chicago.

42) KENDALL, E.C. : J. Biol. Chem., $20: 501 〜 509 ，(1915) . \quad 43)$ 熊岡爽一: ホルモンと臨床，8:291〜296(1960). 44) 熊岡爽一: 内科, $5: 421 \sim 430(1960)$. WSON : Endocrinology, $66: 32 \sim 38$, (1960). 45) KUMAOKA, S., W.L. MONEY and R.W. RA46) KUZELL, W.G., R.W. SCHAFFARZICK, W.E. NAUGLER, P. KOETS, E. A. MAKLE, B. BROWN and B. CHAMPLIN : J. Chronic Disease, $2: 645 \sim 669$, (1955). $\quad 47)$ LEEPER, R.D., R.S. BENUA, J.L. BRENER and R. W. RAWSON : J. Glin. Endocrinol. and Metabol., $20: 1457 \sim 1466$, (1960).

48) LERMAN, J. : J.Clin. Endocrinol. and Metal., $21: 1044 \sim 1053$, (1961). 49) LERMAN, J. and R. PITT-RIVERS : J. Clin. Endocrinol. and Metabol., 15 : 653 655, (1955). 50) LERMAN, J. and R. PITTRIVERS ; J. Clin. Endocrinol. and Metabol., 16 : 1470 1479, (1956). 51) MALMOROS, $\mathrm{H}$. and B. SWAHN : Acta Med. Scand., $145: 361 \sim 369$, (1953). and J.P. PETERS : J. Cin. Invest. $19: 43 \sim 59$, (1940).

52) MAN, E.B., E.F. GILDEA

53) McGEE, L. G. : Am. Int. Med.,

\section{第38巻 第 9 号}


9 : 728 738, (1935). $\quad$ 54) MONEY, W.L., R.I. MELTZER, D. FELDMAN and R.W. RAWSON : Endocrinology, $64: 123 \sim 125,(1959) \cdot \quad$ 55) MONEY, W.L., R.I. MELTZER, J. YOUNG and R.W. RAWSON : Endocrinology, $63: 20 \sim 28$, (1958). 56) MONEY, W.L., S. KUMAOKA, R.W. RAWSON and R.L. KROC: Ann. N. Y. Acad. Science, $86: 521 \sim 544,(1960)$. 57) OLIVER, M.F. and G.S. BOYD : Lancet, I : 124 126, (1957). 58) PAGE, I.H. : Circulation, $10: 1 \sim 27,(1954)$ 59) PETERS, J.P. and E.B. MAN : J. Clin.Invest, $22: 715 \sim 720$, (1943). 60) PETERS, J.P. and E.B. MAN : J. Clin. Invest, $29: 1 \sim 11$, (1950). 61) PITT-RIVERS, R. : Lancet, II : 234 235, (1953). $\quad$ 62) RAWSON, R.W., W.L. MONEY, R.L. KROC, S. KUMAOKA, R.S. BENUA and R.D. LEEPER : Am. J. Med. Sci., $238: 261 \sim 273$, (1959). 63) RAWSON, R.W., J.E. RALL, O.H. PEARSON, J. ROBBINS, H.F. POPPELL and G.D. WEST : Am. J. Med. Sci, $226: 405 \sim 411,(1953)$ 64) ROBBINS, J. and J.E. RALL : J. Clin. Invest, $34: 1331 \sim 1336$, (1955). 65) RUEGAMER, W.R. and F.R. SILVERMAN : Endocrinology, 68 : 564 573, (1961). 66) RUEGAMER, W.R., M.F. ALPERT and F.R. SILVERMAN : Endocrinology, 66:160 166, (1960). 67) SACHS, B.A., E. DANIELSON, M.C. ISAACS and R.E. WESTON : J. Glin. Endocrinol. and Metabol., $18: 506 \sim 515$, (1956). $\quad$ 68) SCHÖNHEIMER, R : Ztscht. Physiol. Chem., $160: 61 \sim$ 76, (1926). 69) SCHOENHEIMER, R. and W.M. SPERRY : J. Biol. Chem., $106: 745 \sim 760$, (1934). 70) Slater, S., M. PERlmutTer, J. PAZ-GARRANZA and M. NUMEROFF : J. Clin. Endocrinol. and Metabol., $20: 401 \sim 408$, (1960). 71) STARR, P. : J. Glin. Endocrinol. and Metabol., $20: 116 \sim 119 .(1960) . \quad 72)$ STARR, P., P. REON, J.E. FREIBRUM and L.A. SCHLEISSNER : Arch. Int. Med., $105: 830 \sim 842,(1960) . \quad 73)$ STASILLI, N.R., R.L. KROG and R.I. MELTZER : Endocrinology, $64: 62 \sim 82$, (1959). 74) STEINER, A. and F.E. KENDALL : Arch. Pathol., 42 : 433 444, (1946). 75) STERLING, K., J.G. LASHOF and E.B. MAN : J. Clin. Invest, $33: 1031 \sim 1035$, (1954). 76) STERLING, K. and R.B. CHODOS : J.Glin. Invest., 35 : 806 813 (1956). $\quad$ 77) STRISOWER. B., J.W. GOFMAN, E.F. GALIONI, A.A. ALMADA and A. SIMON : Metabolism, $3: 218 \sim 227$, (1954). $\quad 78$ ) STRISOWER, B., J.W. GOFMAN, E.F.. GALIONI, J.H. RUBINGER, J. POUTEAU and P. GUZVICH : Lancet, I : 120 123, (1957).

79) STRISOWER, B., P. ELMLINGER, J.W. GOFMAN and O. DELALLA : J. Clin. Endocrinol. and Metabol., $19: 117 \sim 126$, (1959). $\quad$ 80) SURE, B., Z.W. FORD., JR.. R.M. THEIS. and M. GOLDFISGHER : Endocrinology, $28: 806 \sim 815$, (1941). $\quad 81)$ SWAHN, B : Scand. J. Clin. and Lab. Invest, $4: 98 \sim 103,(1952) . \quad 82)$ 田村孝: 新潟医学会誌, $74: 597 \sim 607,(1960)$.

83) TAPLEY, D.F., F.F. DAVIDOFF, W.B. HATFIELD and J.E. ROSS : Am. J. Physiol. 197 : 1021 1026, (1959). 84) TATA, J.R. and C.J. SHELLABARGER : Biochem. J., $72: 608 \sim 613$ (1959). $\quad$ 85) TOMITA, K. and H.A. LARDY : J. Biol. Chem., $219: 595 \sim 604$, (1956).

86) TROTTER, W.R : Lancet, I : 885 889, (1956). 